\title{
Dynamics of the benthic food web in St. Georges Bay, southern Gulf of St. Lawrence
}

\author{
B. T. Hargrave \& G. A. Phillips \\ Marine Ecology Laboratory, Bedford Institute of Oceanography, PO Box 1006, Dartmouth, N.S., B2Y 4A2, Canada
}

\begin{abstract}
In situ rates of oxygen uptake, carbon dioxide and inorganic nitrogen release from sediments at $34 \mathrm{~m}$ depth in St. Georges Bay, Nova Scotia (Canada) increased as temperature of bottom water increased between April and November. Rates of gas and nutrient exchange were linearly related to temperature and regressions were used to estimate daily rates of exchange between sediment and overlying water. Sedimentation of particulate organic carbon from the euphotic zone at depths above bottom which reduced collection of resuspended material was slightly less than carbon released by benthic aerobic respiration between April and November. Anaerobic microbial respiration corrected for aerobic oxygen uptake accounted for approximately $50 \%$ of total carbon dioxide release. Nitrogen sedimentation from the euphotic zone exceeded regeneration of inorganic nitrogenous nutrients from sediments during periods of weak stratification but a balance existed when the water column was stratified. Total inorganic nitrogen release including $\mathrm{N}_{2}$ produced by denitrification was not measured but mineralization could have supplied approximately $20 \%$ of phytoplankton requirements if nutrients released at the sediment were distributed homogeneously to the euphotic zone. Estimates of production by benthic macrofauna, calculated from biomass and assumed annual turnover ratios, equalled from 10 to $30 \%$ of average particulate organic carbon sedimentation at $22 \mathrm{~m}$ for stratified and unstratified periods. Demersal fish production by a similar calculation amounted to from 1 to $7 \%$ of estimated production of macrobenthos.
\end{abstract}

\section{INTRODUCTION}

Studies of energy and material flow through pelagic and benthic aquatic communities usually do not describe the magnitude of organic matter flux not associated with living organisms. Consequently the dynamics of pools of dissolved organic matter and nonliving particulate detritus are not represented in past descriptions of energy flow through marine food webs (Pomeroy 1974, 1979). Although concentrations of organic matter in seawater as dissolved or non-living particulates exceed those present in organisms by 1 to 2 orders of magnitude (Sharp 1973), no standard methods have been developed to measure the turnover of this material. The dynamics of detritus is especially poorly understood in benthic food webs.

Although organic matter is known to be added to sediments through sedimentation, few studies of rates of transfer of elements or energy through a benthic community have been made in conjunction with actual measurements of sedimentation. Studies of food web dynamics in marine waters such as those by Riley (1956) in Long Island Sound, Steele (1974) in the North
Sea and Kremer \& Nixon (1978) in Narragansett Bay have focused primarily on pelagic interactions of phytoplankton production and consumption by herbivorous grazing plankton. Sedimentation rates of phytoplankton were calculated or assumed as a constant loss term and the total detrital carbon flux to the benthos was unmeasured. Many studies (see review by Hargrave 1984) have directly measured particulate sedimentation rates to quantify the supply of organic matter to sediments from the marine pelagic zone. However, the fate of the settled particulate matter was not considered in these studies.

Observations in St. Georges Bay provided an opportunity to relate changes in rates of particulate organic supply measured in 3 separate years to respiration of deposited material by benthic populations in the Bay. Measurements of phytoplankton production and sedimentation and estimates of secondary production by zooplankton during 1977 (Hargrave et al. 1985) showed that the lowest rates of organic supply to the benthos between May and November occurred during the period of summer stratification. The formation of a thermocline permits the development of a tightly 
linked food web of populations of pelagic producer and consumer organisms in the Bay which minimizes loss of organic matter from the water column by sedimentation. Superimposed on this seasonal patterns are effects of resuspension caused by short-term climatic events and the progressive deepening of the mixedlayer throughout the summer. Resuspension and horizontal transport of particulate matter which redistribute previously settled material are important processes in this shallow Bay and they affect the amount and nature of organic matter sedimentation.

Data presented here compare these measures of particulate organic carbon and nitrogen sedimentation with in situ measures of dissolved oxygen, carbon dioxide and inorganic nitrogen flux across the sediment-water interface. Measures of particulate organic carbon and nitrogen in surface sediments are presented to test the idea that decomposition and respiration of organic matter occurs rapidly after deposition. Estimates of benthic macrofauna and demersal fish production are calculated from measures of biomass for comparison with observed rates of organic carbon input.

\section{METHODS}

St. Georges Bay $\left(45^{\circ} 45^{\prime} \mathrm{N}, 61^{\circ} 45^{\prime} \mathrm{W}\right)$ is a shallow bay (mean depth $24 \mathrm{~m}$, maximum depth $42 \mathrm{~m}$ ) on the southwestern coast of the Gulf of St. Lawrence where measurements of plankton production and sedimentation were carried out at 2 stations during 1977 (Hargrave et al. 1985). Observations during 1978 at an offshore location (Station 2, $34 \mathrm{~m}$ bottom depth) sampled previously consisted of mooring of sediment traps at 22 and $25 \mathrm{~m}$ depth (12 and $9 \mathrm{~m}$ above the bottom) (Hargrave \& Prouse 1981). This spacing decreased the collection of resuspended bottom material which increased at depths closer to the bottom yet it exposed traps below the thermocline at least until mid-September when the midlayer usually reached $25 \mathrm{~m}$. Temperature was measured with Nansen reversing bottles on hydrocasts to $30 \mathrm{~m}$. Occasional measurements $1 \mathrm{~m}$ above bottom in June, August and October showed that small differences $\left(<1^{\circ} \mathrm{C}\right)$ existed between temperatures at 30 and $33 \mathrm{~m}$. Thus, bottom water temperature was assumed to be equal that measured at $30 \mathrm{~m}$. Four PVC cylinders ( $7.5 \mathrm{~cm}$ inside dia., $31 \mathrm{~cm}$ length) used to collect settled material were exposed for consecutive 1 wk periods between April 24 and October 30, 1978. Contents of each cylinder were filtered through preweighed glass fiber or precombusted silver filters $(0.8 \mu \mathrm{m}$ Selas Flotronics) and weight was determined after drying to a constant weight at $60^{\circ} \mathrm{C}$. Silver filters were fumed $(30$ min over concentrated $\mathrm{HCl}$ ), dried and analyzed for organic carbon and nitrogen on a Perkin-Elmer 240 elemental analyzer. Samples of sediment were taken each week by dragging a heavy metal cylinder closed at one end along the bottom providing a mixed sample of surface sediment. Samples were frozen in whirl-pac bags until analysis for carbon and nitrogen as described for contents of sediment traps.

Exchange of dissolved oxygen, carbon dioxide and inorganic nitrogen nutrients between sediments and overlying water was measured at Station 2 during 1978 and in one experiment in April 1981. One or 2 benthic chambers similar to those described by Hargrave \& Connolly (1978) were deployed for $24 \mathrm{~h}$ on a polypropylene line tethered to a small surface float. Each clock-driven sampler released spring-loaded syringes to collect eight $50 \mathrm{ml}$ samples of supernatant water at $3 \mathrm{~h}$ intervals from a total volume of $17.1 \mathrm{l}$ enclosed over the sediment $\left(1,452 \mathrm{~cm}^{2}\right)$. Water in chambers was continuously mixed by a battery operated stirrer blade $(30$ rev $\min ^{-1}$ ) which did not disturb the sediment but prevented the formation of concentration gradients. Syringes were filled with $\mathrm{HgCl}_{2}$ solution prior to loading so that the dead volume would contain this fluid for preservation of samples. No measurable changes in dissolved gas or nitrate occurred in syringes containing samples held at a constant temperature when $\mathrm{HgCl}_{2}$ was present or when water from $33 \mathrm{~m}$ was incubated in glass bottles for $24 \mathrm{~h}$. Thus, all changes in dissolved gases and nutrients in water under chambers was assumed to be due only to exchange across the sediment surface.

Dissolved oxygen and carbon dioxide in samples withdrawn from syringes were determined immediately after retrieval of chambers by polarographic and gas chromatographic techniques described in Hargrave \& Connolly (1978). Water samples for dissolved nitrite, nitrate and ammonia were prefiltered into vials through acid-rinsed Millipore $(0.45 \mu \mathrm{m})$ filters in Swinnex holders placed directly on syringes used for sampling. Vials were frozen $\left(-20^{\circ} \mathrm{C}\right)$ until standard colorimetric methods (Strickland \& Parsons 1972) were used to analyze $5 \mathrm{ml}$ aliquots. Flux rates of dissolved material between sediments and water within chambers were calculated by fitting regression lines to timeconcentration curves. Accuracy of chemical analyses of gases and nutrients was approximately $1 \%$ of initial concentrations. No time-concentration plots of measurements from any experiment showed significant non-linear changes and slopes of linear regression curves were calculated as hourly rates over the full period of all incubations.

No attempt was made to use chambers to separate biological and chemical gas or nutrient flux. However, undisturbed cores obtained using a $0.25 \mathrm{~m}^{2}$ box corer or gravity operated corer similar to that described by Pamatmat (1971) were incubated in the laboratory with 
and without formalin to qualitatively assess the importance of oxygen uptake by reduced substances such as sulfides. Magnetic stirrers were used to mix water in cores during incubations at in situ temperatures over 14 to $25 \mathrm{~h}$. Andrews (1980) observed an average of $61 \%$ reduction in oxygen uptake after formalin addition to a final concentration of $1 \%$ in 2 cores collected in August 1978 near Station 2. Six cores collected in April 1981 had an average of $44 \pm 23 \%$ reduction in oxygen uptake with no significant differences between short ( $6 \mathrm{~h}$ ) and long ( $25 \mathrm{~h}$ ) incubations. The use of formalin (or other metabolic inhibitors) to separate chemical and biological oxygen uptake in sediments may underestimate aerobic respiration (oxygen uptake by organisms used to directly oxidize organic matter) (Dale 1978). However, Jørgensen (1982) observed that 90 to $95 \%$ of the sulphide produced by sulphate reducing bacteria in coastal sediments was re-oxidized by oxygen. Approximately half of the oxygen uptake was due to chemical or bacterial sulphide oxidation and half due to aerobic respiration. No separate measurements of sulphate reduction were made in St. Georges Bay for comparison with sediment oxygen uptake, but it was desirable to separate benthic aerobic and anaerobic respiration for comparison with carbon dioxide release. Thus, aerobic respiration was calculated as $50 \%$ of total oxygen consumption on the basis of the observed reduction in oxygen uptake after formalin treatment.

Estimates of aerobic respiration $150 \%$ of total oxygen uptake) as $\mu \mathrm{g}$-at $\mathrm{O}_{2} \mathrm{~m}^{-2} \mathrm{~h}^{-1}$ were expressed as

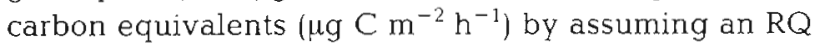
of 1.0 and multiplying by 12 . Carbon dioxide release was considered to arise only from aerobic and anaerobic respiration within the sediment. Inorganic reactions such as precipitation or dissolution could contribute to $\mathrm{CO}_{2}$ exchange but are likely to be unimportant processes in the non-carbonate sediments in St. Georges Bay. Measures of nitrogen flux as $\mu \mathrm{g}$-at $\mathrm{NO}_{2}^{=}$, $\mathrm{NO}_{3}^{-}$and $\mathrm{NH}_{4}^{+} \mathrm{m}^{-2} \mathrm{~h}^{-1}$ were converted to $\mu \mathrm{g} \mathrm{N}$ $\mathrm{m}^{-2} \mathrm{~h}^{-1}$ and summed to calculate the supply of these dissolved nutrients which would be available to support phytoplankton production.

Production by benthic macrofauna and demersal fish has not been measured in St. Georges Bay. However, biomass determinations have been made and these were combined with assumed annual turnover ratios to calculate a range of production rates for comparisons with rates of particulate organic carbon supply. Three $0.25 \mathrm{~m}^{2}$ box cores and four $0.2 \mathrm{~m}^{2}$ Van Veen grabs were collected near Station 2 in April 1981. Sediment was washed through a $0.8 \mathrm{~mm}$ mesh and all macrofauna were removed by hand and preserved. Wet weight determinations were made for all individuals in each sample.
Kenchington (1980) conducted a trawl survey for demersal fish covering randomly distributed stations in St. Georges Bay between May and August 1978. A $15 \mathrm{~m}$ Flounder Trawl of $100 \mathrm{~mm}$ stretched-mesh polypropylene was used with a finer mesh liner in the belly and cod end of the trawl to retain fish that were generally over $100 \mathrm{~mm}$ in length. A bottom area of approximately $13.9 \times 10^{3} \mathrm{~m}^{2}$ was sampled by each trawl. Kenchington calculated biomass of demersal fish present throughout the summer, corrected for differences in catchability between species, to estimate maximum and mean biomass values for the Bay as a whole.

Since sedimentation and benthic carbon dioxide release represent direct measures of carbon exchange, estimates of benthic macrofauna and demersal fish biomass were converted to carbon equivalents for calculation of comparative production rates on this basis. Dry weight was estimated as $22 \%$ of wet weight (based on comparisons of wet-dry weight of representative taxa of benthic macrofauna, $n=16$ ). The value is typical of those generally observed for benthic fauna (Parsons et al. 1984). Organic carbon for both fish and macrofauna was assumed to comprise $35 \%$ of dry tissue weight. Values in benthic molluscs and polychaetes may vary from 30 to $40 \%$ (Hargrave 1978).

\section{RESULTS}

\section{Seasonal and depth differences in sedimentation and temperature}

Changes in sedimentation of particulate organic carbon and nitrogen observed over time and depth in St. Georges Bay during 1978 were similar to those in previous years (Table 1). Minimum sedimentation rates occurred during July and August - the period of maximum stratification. Sedimentation rates also usually increased with depth and although only 2 depths separated by $3 \mathrm{~m}$ were sampled in 1978, large differences in deposition often occurred. These were greatest during April and May (for nitrogen) and during September and October (for carbon) when the water column was poorly stratified. Average sedimentation was higher at $22 \mathrm{~m}$ than at $25 \mathrm{~m}$ in October, because of one measurement between 11 and 22 October when dry matter was deposited at a high rate $10.3 \mathrm{~g}$ $\left.\mathrm{m}^{-2} \mathrm{~d}^{-1}\right)$ and contained a relatively high organic carbon $(8.6 \%)$ and nitrogen $(1.4 \%)$ content. Organic content in settled material was usually $50 \%$ of these values (Hargrave \& Prouse 1981). This event is characteristic of periods when resuspension and lateral transport of particulate matter occur within the Bay. Resuspended material was also enriched with nitrogen rela- 
Table 1. Average daily sedimentation rates for various months in different years at depths of 22 and $25 \mathrm{~m}$ in St Georges Bay at Station 2. Data summarized from Prouse \& Hargrave (1977), Marine Ecology Laboratory (1980), Hargrave \& Prouse (1981) and Hargrave et al. (1985). - : Measurements not made

\begin{tabular}{|c|c|c|c|c|}
\hline \multirow[t]{3}{*}{ Date } & \multicolumn{4}{|c|}{$\mathrm{mg} \mathrm{C} \mathrm{m} \mathrm{m}^{-2} \mathrm{~d}^{-1}$} \\
\hline & \multirow{2}{*}{$\frac{1976}{(25 \mathrm{~m})}$} & \multirow{2}{*}{$\frac{1977}{(25 \mathrm{~m})}$} & \multicolumn{2}{|c|}{1978} \\
\hline & & & $(22 \mathrm{~m})$ & $(25 \mathrm{~m})$ \\
\hline Apr $15-30$ & - & - & 53 & 60 \\
\hline May & - & 118 & 152 & 177 \\
\hline Jun & 73 & 50 & 87 & 113 \\
\hline Jul & 67 & 52 & 61 & 90 \\
\hline Aug & 49 & 35 & 39 & 58 \\
\hline Sep & - & 130 & 133 & 233 \\
\hline Oct & - & 123 & 468 & 397 \\
\hline \multirow{2}{*}{ Nov $1-14$} & - & 236 & - & - \\
\hline & \multicolumn{4}{|c|}{$\mathrm{mg} \mathrm{N} \mathrm{m} \mathrm{m}^{-2} \mathrm{~d}^{-1}$} \\
\hline Apr $15-30$ & - & - & 3 & 7 \\
\hline May & - & 16 & 20 & 41 \\
\hline Jun & 12 & 7 & 14 & 13 \\
\hline Jul & 7 & 7 & 8 & 10 \\
\hline Aug & 6 & 6 & 6 & 7 \\
\hline Sep & - & 18 & 24 & 44 \\
\hline Oct & - & 16 & 79 & 72 \\
\hline Nov $1-14$ & - & 33 & - & - \\
\hline
\end{tabular}

tive to carbon. Average carbon: nitrogen ratios (by weight) in settled material increased from 6.9 to 9.9 between 22 and $32 \mathrm{~m}$ during summer stratification, but lower values (5.9 to 6.5) occurred outside of this period indicating settling of freshly produced organic matter (Hargrave et al. 1985).

In addition to these differences in sedimentation over depth and time, there are year-to-year differences when rates measured at one depth $(25 \mathrm{~m})$ are compared (Table 1). Traps were exposed in the same manner at the same location (Station 2) each year. Average rates observed in every month in 1978 exceeded those in 1977. Differences were not restricted to times when the water column was poorly stratified when variations in resuspension might be expected to cause large differences in the amount of material brought into the water column. Sedimentation of organic carbon and nitrogen during stratification (between June and August) in 1978, the period when resuspension should have been minimized, was increased by 66 to $126 \%$ and 17 to $86 \%$ respectively over rates in 1977 .

Temperature structure also differed in St. Georges Bay between these 2 years. The characteristic summer maxima surface temperature occurred in mid-August in both years, but the thermocline which was established at $15 \mathrm{~m}$ by mid-June in 1977 was present at the same depth by late May in 1978. The delay in forma- tion of the thermocline in 1977 was due to a period of strong NW winds during the last week of May which caused the water column to become almost thermally homogeneous. Bottom water $(30 \mathrm{~m})$ temperature increased from 0.75 to $5.4^{\circ} \mathrm{C}$ within $1 \mathrm{wk}$ during this time (Marine Ecology Laboratory 1980). In 1978, on the other hand, the thermocline was permanently established by late May and it progressively deepened at a rate of $0.15 \mathrm{~m} \mathrm{~d}^{-1}$ over the next $5 \mathrm{mo}$ - a value similar to that observed in earlier years (Hargrave \& Prouse 1981). However, temperatures fell in late July and increased in late August. Thus, although a progressive deepening of the thermocline occurs regularly each summer, intermittent events are superimposed on this trend which result in short-term temperature changes in near bottom water ( $\mathrm{K}$. Drinkwater, pers. comm.). Despite this, warming of water below $30 \mathrm{~m}$ above $10^{\circ} \mathrm{C}$ was restricted to October in both years.

The progressive increase in bottom water temperature between April and November for $3 \mathrm{yr}$ at $30 \mathrm{~m}$ (Fig. 1) could be described by the linear regression:

$$
\begin{gathered}
\mathrm{T}\left({ }^{\circ} \mathrm{C}\right)=-6.57+0.058( \pm 0.003) \\
\text { Julian day }\left(\mathrm{r}^{2}=0.72\right)
\end{gathered}
$$

Slope coefficients (b standard error) derived for 1977 and 1978 were significantly different $(p>0.01)(0.053$ \pm 0.003 and $0.063 \pm 0.004$ ) but the small data base and weekly interval of measurement prevent rigorous evaluation of year-to-year differences. The single regression, derived by combining data from all $3 \mathrm{yr}$, was used to predict temperature for each Julian day between May and early November 1978.

\section{Benthic gas and dissolved nutrient flux}

In situ experiments to measure gas and dissolved mutrient exchange between sediments and overlying water were carried out in 5 experiments in spring, summer and fall during 1978 and 1981. Exchange rates for all variables increased throughout the study period (Fig. 1). A relation between temperature and fluxes was derived by substituting values for Julian days between May 1 (117) and November 15 (319) into the regressions shown in Fig. 1. The following linear regressions were derived between gas and nutrient flux and temperature with the standard error of slope values in parentheses:

$$
\begin{gathered}
\mu g \text {-at } \mathrm{O}_{2} \mathrm{~m}^{-2} \mathrm{~h}^{-1}=407.9+80.7^{\circ} \mathrm{C} \\
\mu \mathrm{g} \text {-at } \mathrm{CO}_{2} \mathrm{~m}^{-2} \mathrm{~h}^{-1}=378.0+64.1^{\circ} \mathrm{C} \\
\mu g \text {-at } \mathrm{N} \mathrm{m}^{-2} \mathrm{~h}^{-1}=11.9+2.5^{\circ} \mathrm{C}
\end{gathered}
$$

with $\mathrm{N}$ equal to the sum of $\mathrm{NO}_{2}^{-}, \mathrm{NO}_{3}^{-}$and $\mathrm{NH}_{4}^{+}$ release. 
Average hourly flux rates were calculated from each equation for derived temperature values at $2 \mathrm{wk}$ intervals from May 1 to November 15. These rates, multiplied by 24 , were assumed to be the average daily flux for each 2 wk period, from which total monthly values
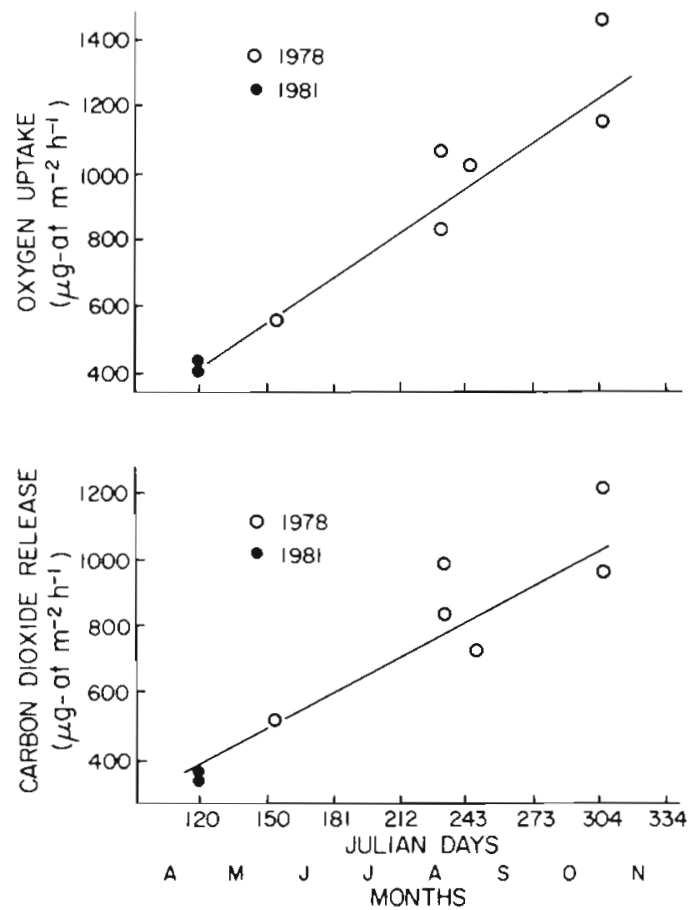

Fig. 1. Sediment oxygen uptake $\left(\mathrm{O}_{2}\right)$, inorganic carbon (total $\left.\mathrm{CO}_{2}\right)$, nitrogen $\left(\mathrm{NO}_{3}^{-}, \mathrm{NO}_{2}^{-}, \mathrm{NH}_{4}^{+}\right.$) release and water temperature (T) between Apr and Nov at an offshore station ( $34 \mathrm{~m}$ depth) in St. Georges Bay. Each value derived from deployment of one benthic chamber described in Hargrave \& Connolly (1978). Linear regressions calculated over time measured as Julian days (JD): $\mathrm{O}_{2}=-122+4.68 \mathrm{JD}\left(\mathrm{n}=8, \mathrm{r}^{2}=0.92\right) ; \mathrm{CO}_{2}=-43.3+3.72 \mathrm{JD}\left(\mathrm{n}=8, \mathrm{r}^{2}=0.87\right) ; \mathrm{N}_{\text {inor }}=-4.6+0.146 \mathrm{JD}\left(\mathrm{n}=8, \mathrm{r}^{2}=0.60\right) ;$

Fig. 2. Summary of rates of particulate organic carbon assimilated by phytoplankton above $22 \mathrm{~m}$, sedimented at 22,25 and $32 \mathrm{~m}$, and released as dissolved inorganic carbon by benthic aerobic and anaerobic respiration during stratified (Jun to Aug) and non-stratified (May, Sep, Oct) in St. Georges Bay at $34 \mathrm{~m}$. Numbers in heavy circles: values determined by direct measurement; other values calculated by difference. Estimates of phytoplankton production derived from Hargrave et al. (1985)
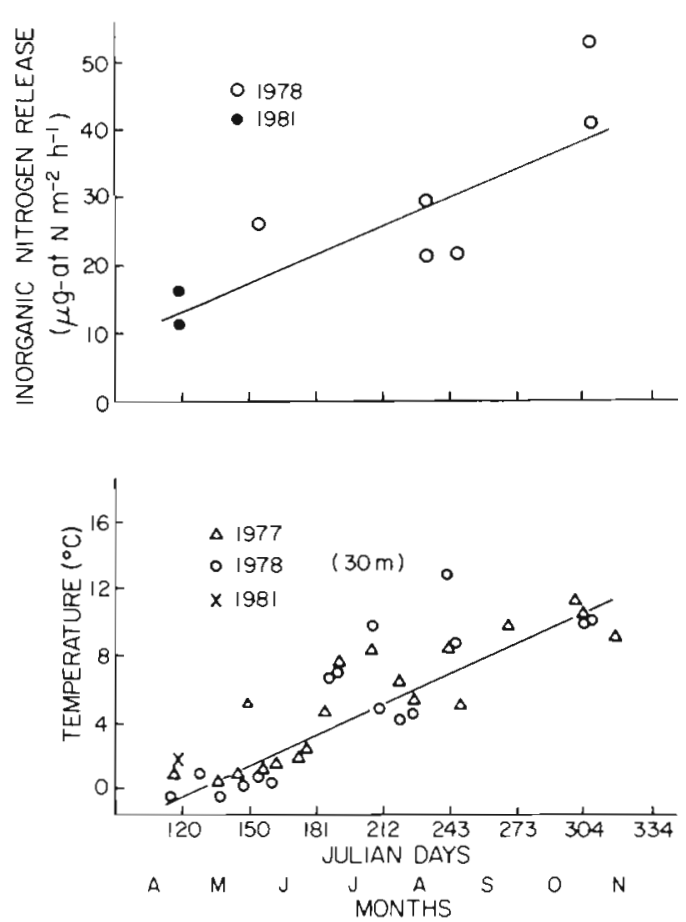
$\mathrm{T}=-6.6+0.058 \mathrm{JD}\left(\mathrm{n}=35, \mathrm{r}^{2}=0.72\right)$

were calculated. The total fluxes for oxygen, carbon dioxide and nitrogen for the period were $3.88,3.36$ and $0.12 \mathrm{~g}$-at $\mathrm{m}^{-2}$, respectively. Since $50 \%$ of the total oxygen uptake was assumed to be due to chemical oxidation of sulphide produced by anaerobic respira-

\section{CARBON FLUX (mg C m-2 $\mathrm{d}^{-1}$ )}

UNSTRATIFIED PERIOD

.

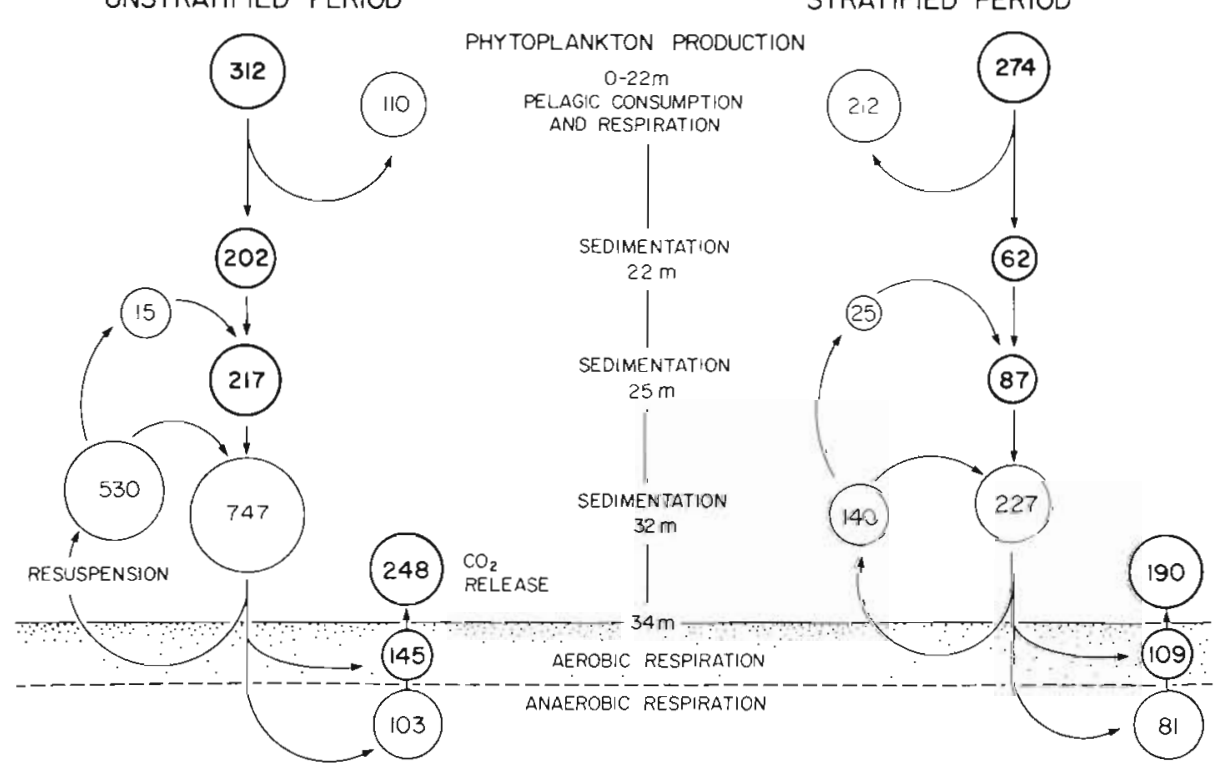




\section{NITROGEN FLUX (mg N $\left.\mathrm{m}^{-2} \mathrm{~d}^{-1}\right)$}

UNSTRATIFIED PERIOD

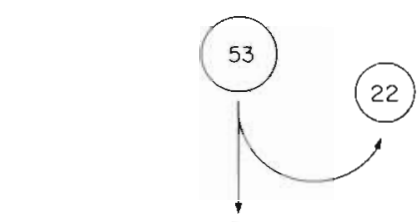

(31)

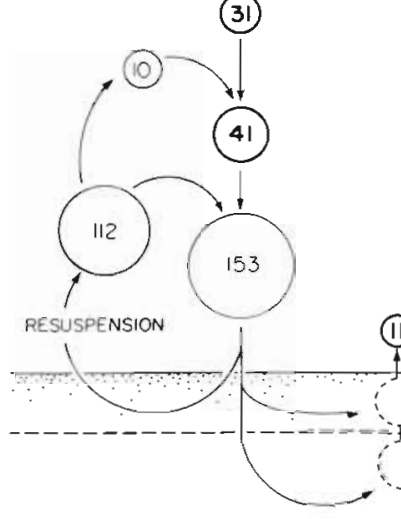

tion (discussed above), aerobic respiration for 6 mo (May to October) expressed as carbon equivalents amounted to $23.3 \mathrm{~g} \mathrm{C} \mathrm{m}^{-2}$. Total benthic respiration (as carbon dioxide release $=$ aerobic + anaerobic respiration) over the same period was equivalent to $40.3 \mathrm{~g} \mathrm{C}$ $\mathrm{m}^{-2}$. Anaerobic respiration, calculated by difference (total carbon dioxide release - aerobic respiration) amounted to $17.0 \mathrm{~g} \mathrm{C} \mathrm{m}^{-2}$. The average $( \pm \mathrm{SD})$ molar ratio $\left(\mathrm{CO}_{2}: \mathrm{O}_{2}\right)$ for carbon dioxide release and oxygen uptake in all experiments was $1.75( \pm 0.30)$. There was no trend in the ratios over time. On the basis of the calculated values of carbon exchange, anaerobic respiration amounted to an average of $73 \%$ of aerobic respiration. The ratio of total oxygen uptake to dissolved nitrogen nutrient release on a molar basis for individual experiments showed no seasonal pattern and varied from 28 to 40 with an average value of 31 $( \pm 2.5)$

\section{Budgets for carbon and nitrogen iluxes}

Measures of phytoplankton production in St. Georges Bay during 1977 (Hargrave et al. 1985) and organic carbon and nitrogen sedimentation during 1978 (Table 1) were combined with calculated benthic fluxes of carbon dioxide and dissolved nitrogen nutrients to construct budgets for exchange between the water column and sediments (Fig. 2 \& 3). Although significant differences existed in sedimentation during stratified and unstratified periods between years, comparisons were only made on the basis of values observed in 1978 .

Some terms in the budget were not directly measured but calculated by difference. Consumption or
STRATIFIED PERIOD

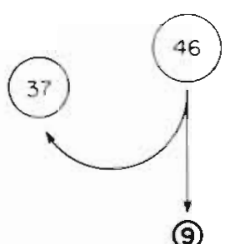

(9)

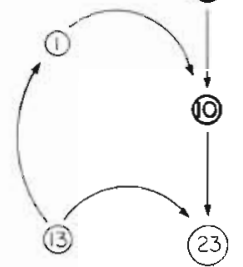

(0)

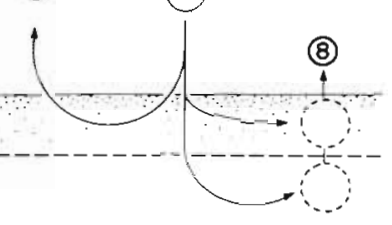

Fig. 3. Summary of rates of particulate nitrogen assimilated by phytoplankton (calculated by assuming a $\mathrm{C}: \mathrm{N}$ ratio (by weight) of 7.0 from measures of inorganic carbon assimilation; Fig. 2) above $22 \mathrm{~m}$, particulate nitrogen sedimented at 22, 25 and $32 \mathrm{~m}$, and released from sediments as dissolved inorganic nitrogen ions as indicated during stratified (Jun to Aug) and non-stratified (May, Sep, Oct) in St. Georges Bay at $34 \mathrm{~m}$. Heavy and light circled numbers as in Fig. 2. Dotted circles: no measurements respiratory loss of photosynthetic production within the euphotic zone (assumed to be $22 \mathrm{~m}$ - twice the average depth of secchi disc visibility Hargrave et al. 1985) was calculated as the difference between phytoplankton production in the surface layer and sedimentation at $22 \mathrm{~m}$. Sedimentation rates at $22 \mathrm{~m}$ amounted to about $20 \%$ of phytoplankton production during the stratified period, but increased to about $60 \%$ at other times (Table 2). Thus, calculated rates of carbon respiration and nitrogen remineralization in the euphotic zone were approximately doubled during months when the water column was most stratified (Fig. $2 \& 3$ ).

Table 2. Ratios of average daily carbon and nitrogen flux (absolute rates in Fig. 2 \& 3) between the water column and sediment in St. Georges Bay during ice-free months during months of strong (Jun, Jul, Aug) and weak (May, Sep, Oct, Nov) stratification

\begin{tabular}{|c|c|c|c|c|}
\hline \multirow[t]{2}{*}{ Ratios } & \multicolumn{2}{|c|}{ Unstratified } & \multicolumn{2}{|c|}{ Stratified } \\
\hline & $\mathrm{C}$ & $N$ & $\mathrm{C}$ & $\mathrm{N}$ \\
\hline $\begin{array}{l}\text { Sedimentation ( } 22 \mathrm{~m}) \text { : } \\
\text { phytoplankton assimilation }\end{array}$ & 0.65 & 0.58 & 0.23 & 0.20 \\
\hline $\begin{array}{l}\text { Increment in sedimentation } \\
(33 \text { to } 22 \mathrm{~m}): \\
\text { sedimentation at } 22 \mathrm{~m}\end{array}$ & 2.69 & 3.93 & 2.66 & 1.55 \\
\hline $\begin{array}{l}\text { Benthic } \mathrm{CO}_{2} \text { release or } \\
\text { nitrogenous nutrient } \\
\text { regeneration: } \\
\text { sedimentation at } 22 \mathrm{~m}\end{array}$ & 1.22 & 0.35 & 3.06 & 0.89 \\
\hline $\begin{array}{l}\text { Benthic } \mathrm{CO}_{2} \text { release or } \\
\text { nitrogenous nutrient } \\
\text { regeneration: } \\
\text { phytoplankton assimilation }\end{array}$ & 0.79 & 0.21 & 0.69 & 0.17 \\
\hline
\end{tabular}


Since sedimentation rates increased with depth during all years of study, it was concluded that particulate matter was added by horizontal transport between depth layers. Sedimentation was not measured at $32 \mathrm{~m}$ during 1978, but the ratio of sedimentation between 25 and $32 \mathrm{~m}$ during stratified and unstratified periods could be determined from data collected in 1977. Sedimentation was always greater at $32 \mathrm{~m}$ but the difference was higher when the thermocline was not present (3.4 and 3.7 times for carbon and nitrogen, respectively). Sedimentation rates measured at $25 \mathrm{~m}$ in 1978 were multiplied by these factors to calculate deposition at $32 \mathrm{~m}$ (Fig, $2 \& 3$ ) assuming that increases in 1978 were similar to those in 1977. However, increases were not similar for carbon and nitrogen. Although absolute rates of carbon sedimentation at all depths were lower during stratification, increases in sedimentation of particulate organic carbon over the depth interval were greater than for nitrogen (Table 2). This contrasted measurements during the unstratified period when nitrogen sedimentation was increased more than carbon at deeper depths.

Daily rates of aerobic and anaerobic benthic respiration and release of dissolved nitrogen nutrients from sediments were increased by 27 to $38 \%$ during the unstratified period (Fig. 2 \& 3). This reflects increases in average bottom water temperature from $4.9^{\circ} \mathrm{C}$ between June and August to $10^{\circ} \mathrm{C}$ between September and October and it is a direct consequence of calculations of gas and nutrient exchange rates as linear functions of temperature. Total carbon respiration in the sediments, however, exceeded the supply of organic carbon from the euphotic zone at $22 \mathrm{~m}$ during both time periods, but the discrepancy was greatest when the water column was stratified (Fig. 2). Benthic aerobic respiration, on the other hand, was less than particulate organic carbon input at $22 \mathrm{~m}$ during the stratified period.

If organic carbon deposited at $32 \mathrm{~m}$ is considered to be available for respiration by benthic organisms, then carbon sedimentation was sufficient to meet both aerobic and anaerobic metabolic demands. Daily rates were balanced to within $16 \%$ during stratification but carbon sedimentation exceeded respiration by 3 times outside of this period. This difference yielded an excess of deposition over consumption of $499 \mathrm{mgC}$ $\mathrm{m}^{-2} \mathrm{~d}^{-1}$ which would provide particulate carbon to balance the calculated resuspension rate $(530 \mathrm{mg} \mathrm{C}$ $\left.\mathrm{m}^{-2} \mathrm{~d}^{-1}\right)$. The same calculations for the stratified period shows that the excess of deposited organic carbon would be insufficient to balance the calculated resuspension rate.

No separate estimates of aerobic and anaerobic metabolic processes involved in nutrient regeneration within the sediments were made. Also, the absence of measurements of $\mathrm{N}_{2}$ release produced by denitrification underestimates total inorganic nitrogen flux. Benthic regeneration of inorganic nitrogenous nutrients, however, amounted to approximately $90 \%$ of particulate nitrogen sedimentation from the euphotic zone during the stratified period (Table 2). During the unstratified period, average daily nutrient flux was $35 \%$ of particulate nitrogen sedimentation at $22 \mathrm{~m}$. This is only a small fraction $(18 \%)$ of the amount of material calculated to be resuspended between 25 and $32 \mathrm{~m}$.

The imbalance between sedimentation and benthic regeneration of carbon and nitrogen is apparent in the disproportionate increases in the 2 measurements between the periods of contrasting stratification. For carbon, an increase in respiration from 190 to $248 \mathrm{mg} \mathrm{C}$ $\mathrm{m}^{-2} \mathrm{~d}^{-1}$ (net value of $58 \mathrm{mg} \mathrm{C} \mathrm{m} \mathrm{m}^{-2} \mathrm{~d}^{-1}$ ) coincided with an increase in sedimentation of $140 \mathrm{mg} \mathrm{C} \mathrm{m}^{-2} \mathrm{~d}^{-1}$ at $22 \mathrm{~m}$ during the 2 periods. The difference in sedimentation at $32 \mathrm{~m}$ (increment of $520 \mathrm{mg} \mathrm{C} \mathrm{m}^{-2} \mathrm{~d}^{-1}$ ) was even greater. Similarly nitrogen mineralization remained approximately constant (8 and $11 \mathrm{mg} \mathrm{N}$ $\mathrm{m}^{-2} \mathrm{~d}^{-1}$ ) despite more than a 3 -fold increase in sedimentation at $22 \mathrm{~m}$ and more than a 6 -fold increase at $32 \mathrm{~m}$ (Fig. 3). Although there were fewer measurements of benthic gas and nutrient exchange during the 6 mo period, the monthly changes in sedimentation with minimum deposition in late summer (Table 1) did not parallel the linear increases calculated for benthic oxygen, carbon dioxide or nutrient flux.

Rates of regeneration of dissolved inorganic nitrogenous nutrients in the water column (calculated as the difference between that fixed during photosynthesis and that sedimented at $22 \mathrm{~m}$ ) exceeded those at the sediment surface. The relative importance of remineralization in the water column was greatest during stratification when $80 \%$ of the inorganic nitrogen assimilated by phytoplankton was regenerated within the euphotic zone (Fig. 3). Nitrogenous nutrients released from sediments could have supported from 17 to $21 \%$ of phytoplankton requirements during all months of observation if the supply was distributed throughout the euphotic zone (Table 2). Rates of inorganic carbon release from sediments were less than carbon assimilation by phytoplankton throughout the study.

\section{Organic carbon and nitrogen in surface sediments}

These calculations do not take into account the burial of organic matter in sediments. Schafer \& Mudie (1980) used discontinuities in stratigraphy of pollen from plants which colonize cleared forest-land to estimate that 20 to $25 \pm 5 \mathrm{~cm}$ had accumulated since 1760 in 2 cores taken at $22 \mathrm{~m}$ depth $3.6 \mathrm{~km}$ off the southwest 
shore of St. Georges Bay. The imprecision of the horizon was due to bioturbation which disturbed the surface layer up to $10 \mathrm{~cm}$ deep and to differences in lithology between the 2 cores. Variability could have been caused by differences in intensity of exposure to wave-induced turbulence between sites.

Although Schafer \& Mudie (1980) did not collect cores from the same site used for sampling in the present study, no significant difference ( $\mathrm{n}=14$, $\mathrm{p}<0.05)$ in average values $( \pm \mathrm{SD})$ of organic carbon $(0.97 \pm 0.44 \%)$ or nitrogen $(0.12 \pm 0.06 \%)$ as percent of dry weight in surficial sediment were observed at 2 stations (22 and $34 \mathrm{~m}$ depth) sampled between June and November 1977 (Marine Ecology Laboratory 1980). Organic content in sediments underwent fluctuations at both sites which were synchronous and similar in magnitude. Vertical profiles of organic carbon and nitrogen were also measured in a core collected near Station 2 in December 1976. There was no gradient in organic carbon $(1.05 \pm 0.1 \%$ sediment dry weight) or nitrogen $(0.14 \pm 0.01 \%$ sediment dry weight) measured at $1 \mathrm{~cm}$ intervals to $11 \mathrm{~cm}$ depth. Water content (porosity) decreased from 78 to $65 \%$ over this depth.

We have therefore assumed that sediment samples taken at Station 2 in 1978 are representative of finegrain soft sediments deposited at other locations in the central region of the Bay with measures of organic content in the upper few $\mathrm{cm}$ characteristic of those to $25 \mathrm{~cm}$ depth. If average values for water, organic carbon and nitrogen content for the upper $25 \mathrm{~cm}$ are taken as $70,0.97$ and $0.12 \%$ respectively, $1 \mathrm{~cm}^{3}$ of sediment contains $3 \mathrm{mg} C$ and $0.4 \mathrm{mg} N$. If sediment has accumulated at a rate of $0.1 \pm 0.05 \mathrm{~cm} \mathrm{yr}^{-1}$ (discussed above), average annual burial rates are $3 \mathrm{~g} \mathrm{C} \mathrm{m}^{-2}$ and $0.4 \mathrm{~g} \mathrm{~N} \mathrm{~m}^{-2}$. These burial rates of organic carbon and nitrogen amount to from 6 to $7 \%$ of average sedimentation rates measured at $22 \mathrm{~m}$, and 0.6 to $3.5 \%$ of rates at $32 \mathrm{~m}$ (Fig. $2 \& 3$ ).

Since the rates of accumulation of organic matter by burial are small relative to rates of supply (either by direct sedimentation or resuspension), it might be expected that short-term pulses of enhanced organic matter sedimentation, discussed in Hargrave et al. (1985), would not significantly change sediment organic content. Also, the daily flux of organic carbon and nitrogen at $22 \mathrm{~m}$ amounted to $<1 \%$ of the accumulated pool of organic matter present to $1 \mathrm{~cm}$ depth in surface sediments. Standing stocks in the upper $1 \mathrm{~cm}$ of sediment based on the above percentages of water, organic carbon and nitrogen amount to $30 \mathrm{~g} \mathrm{C} \mathrm{m}^{-2}$ and $4.2 \mathrm{gN} \mathrm{m}^{-2}$. However, levels of organic carbon and nitrogen in surficial sediments collected during 1977 and 1978 were not constant between May and November (Fig. 4). No clear trend

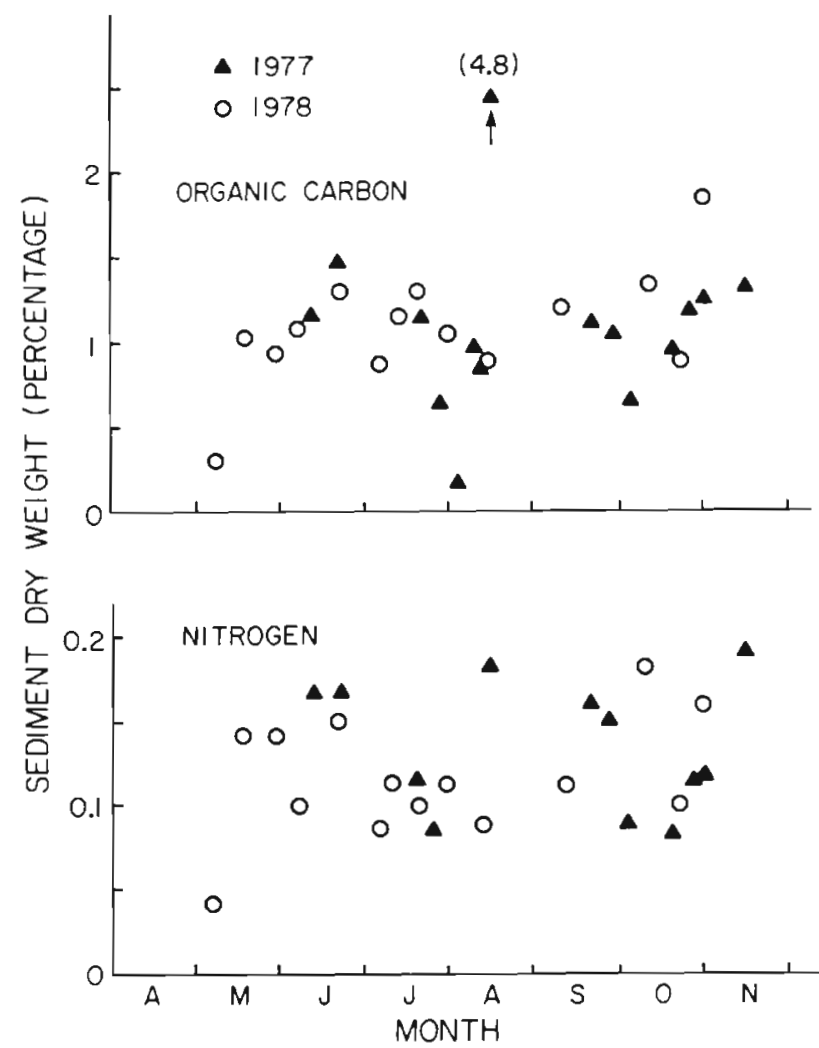

Fig. 4. Organic carbon and nitrogen in surface (upper $1 \mathrm{~cm}$ ) sediment as percent dry weight. Samples collected at Station 2, $34 \mathrm{~m}$ depth, over $2 \mathrm{yr}$. Arrow: sample enriched with organic carbon without corresponding increase in nitrogen content

appeared when data from the 2 yr was combined but minimum values $(0.29$ and $0.04 \%$ respectively) were observed on the first sampling date in 1978 (8 May) and maximum values (1.85 and $0.18 \%$ ) occurred in October. There was a general pattern to changes in carbon:nitrogen ratios (by weight) which increased from minimum values (approx. 7) in May to a maximum value (12.9) in July with a decrease to minimum values by October.

\section{Production by benthic macrofauna and demersal fish}

Van Veen grab samples for benthic macrofauna yielded an average wet biomass value of $105.6 \mathrm{~g} \mathrm{~m}^{-2}$ (range 68.5 to $142.8 \mathrm{~g} \mathrm{~m}^{-2}$ ) while box cores contained $95.6 \mathrm{~g} \mathrm{~m}^{-2}$ (range 75.2 to $135 \mathrm{~g} \mathrm{~m}^{-2}$ ). Van Veen grabs were full (to at least $20 \mathrm{~cm}$ depth) with relatively intact surfaces while the box core was over $30 \mathrm{~cm}$ in length. A large holothurian Molpadia oolitica (Pourtales) was present in 2 box cores but no individuals occurred in grab samples. Polychaetes - Sternaspis scutata (Ranzani), Lumbrineris fragilis (Müller), Nephtys spp. and various species of Maldanidae - were numerically the 
most dominant group in the macrofauna accounting for more than $50 \%$ of the biomass. However, individual species were heterogeneous in their distribution and contributed in varying proportions to the total biomass. Conversion of wet to dry weight and organic carbon yielded variable values for macrofauna biomass between 5 and $11 \mathrm{~g} \mathrm{C} \mathrm{m}^{-2}$. If an average production : biomass (P:B) ratio of 2.0 is assumed for this fauna (Mills \& Fournier 1979), annual production distributed equally throughout the year would be between 27 and $60 \mathrm{mg} \mathrm{C} \mathrm{m} \mathrm{m}^{-2} \mathrm{~d}^{-1}$. This equals from 10 to $30 \%$ of the average value for particulate organic carbon deposition at $22 \mathrm{~m}$ during the unstratified period with the higher value equivalent to sedimentation rates during stratification (Fig. 2). Since no estimates of monthly production by macrofauna were made, there is no basis for making comparisons with sedimentation on other time scales

Similar calculations of potential production may be made for demersal fish. Kenchington's (1980) survey estimated trawlable biomass of juvenile and adult fish $>100 \mathrm{~mm}$ in length. Most common demersal species, white hake Urophysis tenuis, american plaice Hippoglossoides platessoides, winter flounder Pseudopleuronectes americanus, and Atlantic cod Gadus morhua were between 100 and $500 \mathrm{~mm}$ in length. Production : biomass ratios for fish populations depend on organism size and generation time, but annual values between 0.1 and 1.0 have been observed for a variety of species (Banse \& Mosher 1980). The most abundant demersal species in St. Georges Bay have life spans of up to several years and since bottom water is generally $<10^{\circ} \mathrm{C}$, values of 0.1 to 0.5 may be appropriate for calculating potential production.

Kenchington calculated average total biomass from mean catch during June and July (corrected for catchability by multiplying trawlable biomass by 3.5) as $9.5 \mathrm{~g}$ wet weight $\mathrm{m}^{-2}$. A maximum value was 3 times as great. If fish are $70 \%$ water and $35 \%$ of tissue dry weight is organic carbon (as assumed for macrobenthos), mean standing crop during the summer is approximately $1 \mathrm{~g} \mathrm{C} \mathrm{m}^{-2}$. Using the lower and upper turnover estimates, daily production averaged over 1 yr would vary from 0.3 to $1.4 \mathrm{mg} \mathrm{C} \mathrm{m}^{-2} \mathrm{~d}^{-1}$. Maximum biomass estimates would yield production values of 0.9 and $4.2 \mathrm{mg} \mathrm{C} \mathrm{m}^{-2} \mathrm{~d}^{-1}$ - one order of magnitude lower than rates calculated for benthic macrofauna.

\section{DISCUSSION}

\section{Sources of organic matter for the benthos}

Previous studies in St. Georges Bay have shown that changes in sedimentation between April and No- vember follow a sequence described for temperate coastal waters by Smetacek et al. (1984). During summer, a tightly coupled pelagic food web consumes and respires almost all of the products of phytoplankton production and sedimentation rates of particulate matter are low. During fall, the water column mixes to deeper depths. Nutrients accumulated in stratified bottom water, arising by regeneration from settled debris and sediments, are distributed to the euphotic zone to stimulate production. Lowered herbivore populations due to predation and falling temperatures result in reduced consumption of phytoplankton production and the benthos receives an increased supply of organic matter (Hargrave et al. 1985).

The present study extends our previous observations in St. Georges Bay to show that year-to-year differences in absolute rates of sedimentation occur, perhaps due to variation in conditions of stratification. Values in all years, however, were highest during April-May and September-October when the water column became more thermally homogeneous and when biomass of grazing herbivores was low. High rates of sedimentation when stratification is weak or absent must also reflect processes of particle resuspension and advection since sedimentation increases with depth. Advective water movement can redistribute previously settled material to give apparent rates of sedimentation which equal or exceed possible supply by phytoplankton production (Smetacek 1980). Walsh (1983) reviewed data from several marine areas and concluded that resuspension and seaward transport of phyto-detritus were common processes which removed particulate organic carbon from shelf ecosystems.

Measurements of sedimentation where traps were exposed close to the bottom have shown enhanced deposition due to sediment resuspension (Davies 1975, Webster et al. 1975). Hartwig (1976) placed traps close to the sediment surface near the California coast and observed that particulate organic carbon was derived from both resuspended and freshly deposited material in approximately equal amounts. Mooring of traps over a range of depths in St. Georges Bay allowed the magnitude of resuspension to be calculated for 2 depth layers. Rates were an order of magnitude higher over the deepest layer (25 to $32 \mathrm{~m}$ ) with a much smaller increment between 22 and $25 \mathrm{~m}$ (Fig. 2 \& 3). The observations imply that particles settled in traps suspended $10 \mathrm{~m}$ above bottom originated primarily by downward settling from the euphotic zone while material collected at deeper depths included laterally advected resuspended particles. Rates of deposition of resuspended material between 25 and $32 \mathrm{~m}$ (200 to $700 \mathrm{mg} \mathrm{C} \mathrm{m}^{-2} \mathrm{~d}^{-1}$ ) in St. Georges Bay were less than the value ( $3 \mathrm{~g} \mathrm{C} \mathrm{m}^{-2} \mathrm{~d}^{-1}$ ) observed by Hartwig (1976) $1 \mathrm{~m}$ above bottom. The high energy environment also 
prevented accumulation of organic matter in Hartwig's study.

Although the origins of material and mechanisms of movement have not been identified, excess particulate carbon and nitrogen sedimentation between 25 and $32 \mathrm{~m}$ during unstratified periods, which exceeded phytoplankton carbon fixation and nitrogen assimilation as well as particle deposition from the euphotic zone, indicate the magnitude of resuspension rates in St. Georges Bay. Rates of resuspension were considerably reduced ( $73 \%$ for carbon, $88 \%$ for nitrogen) during periods of stratification, but even then, they exceeded sedimentation at $22 \mathrm{~m}$ (Table 2).

High carbon : nitrogen ratios and low organic carbon and nitrogen content in particulate matter settled during summer stratification showed that the presence of a well-developed pelagic community of grazing organisms reduced the amount and quality of deposited material. This phenomenon, discussed by Smetacek (1980) for Kiel Bight and found in other coastal waters (Hargrave 1980), seems inconsistent with the observation that herbivorous plankton produce fecal pellets which are dense and sink rapidly (Komar et al. 1981, Lewis \& Syvitski 1983). Fecal pellets contributed $<2 \%$ of the dry weight of material settled at $25 \mathrm{~m}$ in St. Georges Bay except during June and July when values up to $5 \%$ occurred (Hargrave et al. 1985). Enrichment of settled material by resuspended particles would dilute the contribution of fecal pellets to the total weight deposited, but this would be minimized during stratification.

The low percentage contribution of fecal pellets to settled material must reflect rapid consumption, microbial degradation and disaggregation that fecal material undergoes in these warm $\left(10\right.$ to $\left.20^{\circ} \mathrm{C}\right)$ surface waters during the summer. Chlorophyll a daily loss rates decreased from $>20 \%$ of suspended concentration settled $\mathrm{d}^{-1}$ to $<0.5 \%$ during this period (Hargrave \& Prouse 1981) as would be expected if consumption of products of phytoplankton production occurred before particles were deposited.

The idea that population size of grazing organisms is set by availability of particulate food resources is supported by a theoretical model of phytoplankton growth (Jamart et al. 1979). The formation of a deep chlorophyll maximum layer was modelled by linking zooplankton ingestion to daily gross primary production. Changes in chlorophyl distribution in the model occurred in a manner which appeared to optimize the transfer of organic carbon to herbivore grazers. Actual observations of phytoplankton and copepod biomass and productivity in different areas of the North Sea (Fransz \& Gieskes 1984) showed that during summer months copepod grazing matched primary production in all areas. High grazing pressure maintained a balance between phytoplankton and zooplankton only during this time of year.

Sources of particulate organic matter other than settling products derived from phytoplankton and resuspended detritus and sediment may contribute to organic matter supply to the benthos in St. Georges Bay. No measures of macrophyte production have been made but low carbon: nitrogen ratios and relatively high organic carbon ( 2 to $8 \%$ ) and nitrogen $(0.3$ to $1.7 \%$ ) as a percent of dry weight in material deposited in traps during times of weak stratification could reflect input of particulate detritus produced by macrophytes. Ascophyllum and Laminaria are common in littoral areas and often occur as stranded debris along beaches in the Bay after storms. Growth of many macrophytes, especially those with long blades, is balanced by erosion of material from distal ends and production of dissolved and particulate organic matter on an areal basis in some coastal waters has been shown to exceed that by phytoplankton (Mann 1982). The widespread distribution of macrophytes attached to hard substrates around the perimeter of the Bay indicates that they may be a significant source of particulate and dissolved organic matter to this ecosystem. Comparison of particulate organic carbon and nitrogen fluxes in the water column and that at the sediment surface with phytoplankton production alone (as in Table 2, Fig. $2 \& 3$ ) are misleading if macrophytes contribute significantly to the production of suspended and settled particulate matter.

Graf et al. (1983) concluded that organic matter in resuspended matter and input of macrophyte debris were the primary causes of increased metabolic activity in surface sediment in Kiel Bight during winter. Similar conditions arose following settling of phytoplankton blooms in spring and autumn. In a subsequent paper, Graf et al. (1984) reported that rates of sediment carbon demand, calculated from heat production, were higher than could be supported by vertical settling of particulate matter. They concluded that near-bottom transport provided a source of organic matter not measured in traps suspended above bottom. Some of this transport, if it occurred in St. Georges Bay, would be included in the calculated values of resuspension which increased sedimentation at $32 \mathrm{~m}, 2 \mathrm{~m}$ above the bottom.

Material settled in sediment traps at 22 and $25 \mathrm{~m}$ during 1978 had an average dry-weight organic carbon and nitrogen content of 5.2 and $0.75 \%$ (Hargrave \& Prouse 1981). These levels exceeded those in the sediment by approximately 1 order of magnitude (Fig. 4). This organically enriched material could collect on the bottom without being immediately mixed into surface sediment. If it was not incorporated it would be available to be transported near the bottom as Graf et al. 
(1984) suggested. Our method of dragging a weighted cylinder to collect sediment would mix this material with unenriched subsurface layers to give a heterogenous mixture of recent and older deposits. Resuspension and bioturbation would also mix a thin layer of organically rich particles deeper into the sediment. In either case, our sampling method would not reflect the actual concentration present at the sediment surface. The markedly lower organic content of bottom sediments relative to that settled in sediment traps could also reflect consumption, microbial degradation and remineralization which occurs soon after deposition.

\section{Benthic metabolism and nutrient regeneration}

Seasonal and geographic differences in benthic oxygen consumption and dissolved nutrient flux have been correlated with variations in supply of oxidizable organic matter to sediments in only a few studies. Increases of an order of magnitude in heat production and oxygen uptake 1 mo after the seasonal maximum sedimentation of particulate organic carbon in Kiel Bight (Graf et al. 1984, Smetacek et al. 1984) show the rapid response which follows input of organic matter to shallow water sediments. Even in a deeper eutrophic coastal bay, Hargrave (1980) observed that maximum aerobic respiration in sediment coincided with seasonal maximum rates of nitrogen sedimentation. A weaker correlation between aerobic benthic oxygen uptake and particulate organic carbon supply and increased deposition of nitrogen during the fall which did not stimulate oxygen uptake, implied that the oxidation of organic matter by the benthos was determined by both quantity and quality of particulate matter sedimented.

Several studies have compared seasonal changes in benthic oxygen uptake, carbon dioxide release and dissolved nutrient flux individually with temperature variation throughout the year. Van Es (1982) reviewed previous studies of benthic oxygen uptake in shallow coastal sediments and discussed problems of interpreting correlations with temperature when benthic biomass and organic supply also vary seasonally. His summary shows surprisingly similar results in different locations with rates of total oxygen uptake from 500 to $1,400 \mathrm{mg} \mathrm{O} \mathrm{O}_{2}^{-2} \mathrm{~d}^{-1}$. The corresponding rate in St. Georges Bay, averaged between April and November, was $341 \mathrm{mg} \mathrm{O} \mathrm{O}_{2} \mathrm{~m}^{-2} \mathrm{~d}^{-1}$; however, a large fraction $(\approx 50 \%)$ was due to chemical oxidation. The value is consistent with observations in other areas with water depth between 10 and $100 \mathrm{~m}$ (Zeitzschel 1980).

There have been few studies of inorganic carbon release from sediments. Nixon et al. (1980) measured rates from 50 to $1,700 \mu \mathrm{M} \mathrm{m}^{-2} \mathrm{~h}^{-1}$ in central Narragan- sett Bay where the ratio of oxygen uptake and carbon dioxide release during the year was 0.99 . Howes et al. (1984) measured rates 1 to 2 orders of magnitude higher in a Spartina salt marsh. Sulphate reduction, measured simultaneously with gas exchange, accounted for about $50 \%$ of total sediment metabolism and changes in oxygen uptake and carbon dioxide release over 1 yr were similar in magnitude $\left(\mathrm{CO}_{2}: \mathrm{O}_{2}\right.$ = 1.03). In contrast, Hargrave \& Phillips (1981) found an average ratio of 2.7 in organically rich intertidal sediment. Rates of carbon dioxide release in St. Georges Bay (400 to $1,200 \mu \mathrm{M} \mathrm{m}^{-2} \mathrm{~h}^{-1}$ ) were similar to the range of values for total oxygen uptake with an average ratio of 1.75 . However, residual oxygen uptake after poisoning with formalin indicated that $50 \%$ of the oxygen consumed was used to oxidize reduced substances. The observations show that carbon respiration by aerobic and anaerobic pathways in many coastal sediments can be approximately equal (Jørgensen 1982, Howes et al. 1984). Oxidation of reduced end-products of anaerobic respiration such as sulphides must occur within surface sediments to yield ratios of $+\mathrm{CO}_{2}:-\mathrm{O}_{2} \approx 1$. This apparently occurs in highly bioturbated sediments with deep penetration of dissolved oxygen as well as in salt marsh sediments with shallow oxygen penetration.

Measurements of low rates of benthic nitrogenous nutrient regeneration relative to oxygen uptake by intertidal (Helder et al. 1983) and coastal sediments (Hopkinson \& Wetzel 1982, Seitzinger et al. 1984) were thought to reflect the occurrence of denitrification in deposits well supplied with oxygen. A similar situation may occur in St. Georges Bay. Release of dissolved $\mathrm{NO}_{2}^{-}, \mathrm{NO}_{3}^{-}$and $\mathrm{NH}_{4}^{+}\left(10\right.$ to $\left.50 \mu \mathrm{M} \mathrm{m}^{-2} \mathrm{~h}^{-1}\right)$ fell within the range of values reported for cores incubated in the laboratory taken from water depths $<70 \mathrm{~m}$ in the midAtlantic Bight (12 to $38 \mu \mathrm{M} \mathrm{m}^{-2} \mathrm{~h}^{-1}$ ) (Harrison et al. 1983) and at offshore stations in the eastern North Pacific ( 1 to $40 \mu \mathrm{M} \mathrm{m}^{-2} \mathrm{~h}^{-1}$ ) (Smith et al. 1983) where oxygen penetration into sediments may permit denitrification and the production of $\mathrm{N}_{2}$. Order-of-magnitude higher rates have been measured in estuarine (Nixon et al. 1980, Fisher et al. 1982, Lyons et al. 1982, Boynton \& Kemp 1985) and shallow coastal waters (Propp et al. 1980, Hopkinson \& Wetzel 1982, Flint \& Kamykowski 1984). Rates of organic matter sedimentation are probably greater and oxygen penetration into sediments may be less in these areas than in St. Georges Bay. High rates of release of nitrogen containing nutrients from sediments in the Hudson Shelf Trough and New York Harbour (250 to $320 \mu \mathrm{M}$ $\mathrm{m}^{-2} \mathrm{~h}^{-1}$ ) (Harrison et al. 1983) undoubtedly reflect enhanced organic matter input.

The ratio of $\mathrm{O}: \mathrm{N}$ exchange across the sediment in St. Georges Bay (mean value of 32 from the ratio of slope 
coefficients, Fig. 1) departs significantly from that expected $(13.25)$ if organic matter is oxidized to $\mathrm{NH}_{4}^{+}$. The value is similar to observations in other coastal embayments (20 to 40) (Nixon et al. 1976. Hopkinson \& Wetzel 1982) and with intertidal sediments (Rutgers van der Loeff et al. 1981). Fisher et al. (1982) and Boynton \& Kemp (1985) discussed factors which influence the lack of stoichiometric ratios between elements exchanged between sediment and water. Seitzinger et al. (1984) estimated that up to $49 \%$ of the oxygen consumed by sediments in Narragansett Bay was used for nitrification with denitrification responsible for mineralizing up to $35 \%$ of the organic nitrogen added to the sediments. Sorption and mineral equilibria reactions may also affect $\mathrm{NH}_{4}^{+}$concentrations in pore water such that amounts bound to particles increase with increasing concentration (Rosenfeld 1979).

Linear increases in rates of gas and nutrient exchange which were correlated with linear increases in temperature over $6 \mathrm{mo}$ in our study are similar to observations reported by van Es (1982). The results contrast exponential (Hargrave 1969, Nixon et al. 1976) or non-linear (Fisher et al. 1982) relations described in other studies. Curvilinear functions could describe the relatively small number of observations in our study but linear regressions fit the data more significantly. The range of temperature is also different in various studies. A seasonal temperature change up to $25 \mathrm{C}^{\circ}$ in many studies contrasts the $12 \mathrm{C}^{\circ}$ range in St. Georges Bay. The general trend of increasing rates of organic carbon and nitrogen sedimentation as temperature increased between May and November (Table 1), is consistent with the linear increase in gas and nutrient exchange over this limited temperature range.

Release of inorganic carbon (due to aerobic respiration) and nitrogenous nutrients were equivalent to between 74 and $89 \%$ of particulate organic carbon and nitrogen sedimented at $22 \mathrm{~m}$ in St. Georges Bay when temperature increased from 2 to about $8^{\circ} \mathrm{C}$ during the period of stratification. Higher rates of sedimentation in May and following August did not coincide with a proportionate increase in benthic regeneration of inorganic carbon and nutrients, despite the highest seasonal temperatures $\left(>8^{\circ} \mathrm{C}\right)$ during the fall and differences in the quality of organic matter settled during stratified and unstratified periods. Also, there could be seasonal changes in denitrification, as observed by Boynton \& Kemp (1985). The flux measures of dissolved nitrogen containing nutrients from the sediment do not include estimates of $\mathrm{N}_{2}$ release and thus a complete nitrogen budget cannot be derived.

The seasonal occurrence of denitrification might partially explain why measured benthic nitrogen release was only $35 \%$ of particulate sedimentation at $22 \mathrm{~m}$ during the unstratified period with the rates approximately equal during stratification. The supply of organic carbon from this depth, on the other hand, was never sufficient to meet aerobic and anaerobic respiratory demands during the 6 mo of observation (Fig. 2). A reservoir of buried organic carbon sedimented prior to mid-April, which was oxidized at a slower rate than nitrogen, would explain the difference. Observations in St. Georges Bay between January and November 1978 showed that maximum concentrations of suspended particulate organic carbon, nitrogen and chlorophyll a occurred during February (Hargrave \& Prouse 1981). No sedimentation rates were obtained during the winter since drift ice prevented mooring of traps. However, the absence of large populations of herbivorous plankton in tows during the winter implies that a large fraction of this suspended organic matter would have sedimented.

The release rates of inorganic nitrogenous nutrients from sediments in St. Georges Bay could have supplied $17 \%$ of phytoplankton requirements during stratification and $21 \%$ before and after this period. This is greater than $7 \%$ of phytoplankton requirements potentially supplied by benthic regeneration on the outer shelf of the mid-Atlantic Bight (Harrison et al. 1983) but it is comparable with the range of values (13 to $40 \%$ ) observed in Chesapeake Bay (Boynton \& Kemp 1985) and an average value of $35 \%$ derived in a comparison of results from 10 estuarine and coastal locations (Fisher et al. 1982)

The importance of remineralization in the water column for supplying phytoplankton nitrogen requirements, particularly during stratification, is confirmed by the observation that only $20 \%$ of the nitrogen assimilated by phytoplankton was deposited (Table 2). By inference, $80 \%$ of phytoplankton requirements were met by assimilation of regenerated nitrogen (e.g. $\mathrm{NH}_{4}^{+}$) formed within the euphotic zone during this period. This gives an indirect estimate $120 \%$ of the total) of 'new' production described by Eppley \& Peterson (1979) as the proportion of total production supported by vertical transport of dissolved inorganic nutrients into the euphotic zone. Harrison (1978) concluded that rates of regenerative and assimilative fluxes of $\mathrm{NH}_{4}^{+}$were closely linked in the euphotic zone of enclosed water columns. An inverse relation between total phytoplankton production and the fraction supported by regeneration of $\mathrm{NH}_{4}^{+}$derived by Harrison (1980) indicated that at levels of primary production observed during periods of stratification in St. Georges Bay (300 mg C m $\left.\mathrm{m}^{-2} \mathrm{~d}^{-1}\right)$, approximately $80 \%$ would be due to regeneration. An earlier comparison of phytoplankton production and sedimentation in St. Georges Bay also showed that about $90 \%$ of the organic carbon produced was recycled above the thermocline (Hargrave et al. 1985). 


\section{Pelagic and benthic losses of organic matter}

Estimates of consumption and respiration of organic matter in St. Georges Bay as the difference between carbon fixed by phytoplankton and that sedimented (Fig. 2) were highest during stratification $(212 \mathrm{mgC}$ $\mathrm{m}^{-2} \mathrm{~d}^{-1}$ equivalent to $26 \mathrm{mg} \mathrm{O}_{2} \mathrm{~m}^{-3} \mathrm{~d}^{-1}$ averaged over the upper $22 \mathrm{~m}$ ) when water temperature increased in the surface mixed layer to maximum values. Respiration in coastal waters varies from 1 to $200 \mathrm{mg} \mathrm{O}_{2} \mathrm{~m}^{-3}$ $\mathrm{d}^{-1}$ (Williams 1984) with higher rates generally associated with increased levels of primary production. The importance of utilization above the thermocline is shown by the small loss of particulate organic carbon by sedimentation discussed above and the low loss rates of suspended organic carbon, nitrogen and pigments $(<5 \%$ of suspended concentrations sedimented $\mathrm{d}^{-1}$ ) (Hargrave \& Prouse 1981). Pelagic consumption of the products of higher rates of phytoplankton production during the unstratified period was reduced by $50 \%\left(13 \mathrm{mg} \mathrm{O}_{2} \mathrm{~m}^{-3} \mathrm{~d}^{-1}\right)$ when water temperature was lower. Loss of up to $65 \%$ of the particulate organic carbon produced by phytoplankton through sedimentation (Table 2) would reduce the amount available for respiration above $22 \mathrm{~m}$.

Consumption of organic carbon by pelagic organisms above $22 \mathrm{~m}$ in St. Georges Bay and by the benthos were approximately equal during stratification. However, during the unstratified period, when sedimentation was increased, rates of benthic respiration were more than twice those in the water column. Other studies have also shown that benthic metabolism consumed more organic matter than was respired in the water column. Garside \& Malone (1978) calculated an oxygen budget for the New York Bight to estimate that more carbon was deposited and respired in the sediments than was respired in the water column, but as in St. Georges Bay, rates were of similar magnitude. Very high rates of benthic metabolism may occur in shallow waters. Woodwell et al. (1979) calculated that benthic respiration accounted for $>50 \%$ of total heterotrophic respiration in Flax Pond.

The relative magnitude of pelagic and benthic losses through respiration depend on water depth and absoIute rates of organic matter supply (Suess 1980). In deep coastal and oceanic waters, rates of respiration in the water column exceed those in the sediment (Riley 1956, Raine \& Patching 1980, Taft et al. 1980, Hargrave 1984). Greater water depth allows more time for decomposition before particulate matter reaches the bottom and thereby enhances pelagic utilization. Increased primary production also results in a higher proportion of consumption in the water column (Hargrave 1973). This occurred seasonally in St. Georges Bay when populations of planktonic grazers reduced sedimentation during summer while phytoplankton production was increasing (Hargrave et al. 1985) and rates of respiration in the water column were also increased (Fig. 2).

Organic matter not consumed in the water column or surface sediments is available for resuspension and advective transport, or in depositional environments accumulates in bottom deposits. Burial rates are usually a small fraction of total depositional flux, however. Accumulated organic carbon at depths $>3,000 \mathrm{~m}$ near the Pacific-Antarctic Ridge was estimated to be equivalent to 6 to $16 \%$ of sedimentation with higher values (up to $28 \%$ ) in areas of high primary production on the Peru continental margin (Reimers \& Suess 1983). Calculated burial rates for organic carbon and nitrogen in St. Georges Bay were a similar fraction (3 to $13 \%$ ) of that sedimented at $22 \mathrm{~m}$. Estimated resuspension rates below $25 \mathrm{~m}$ were 2 orders of magnitude greater than burial rates. Hartwig's (1976) observations in La Jolla Bight were mentioned above. No permanent accumulation of organic matter at his study site occurred because of resuspension and sediment movement.

Mud and sand in central areas of St. Georges Bay, where organic content at 21 and $34 \mathrm{~m}$ was comparable and showed similar seasonal changes (Marine Ecology Laboratory 1980), are indicative that depositional areas occur in the Bay. Enhanced sedimentation with increasing depth shows that accumulation of particulate matter in deep water may arise through resuspension and transport. Petrie \& Drinkwater (1978) described the clockwise gyre which forms during summer in surface waters (upper $20 \mathrm{~m}$ ) of St. Georges Bay. Flow at $30 \mathrm{~m}$ is predominantly out of the Bay but water leaving on the western side may return by advection on the eastern side. However, the net effect of this exchange in transporting particulate matter is unknown.

Despite these uncertainties of retention of resuspended particulate matter, synchronous changes in organic matter content in surficial sediments at 2 stations over 6 mo (Marine Ecology Laboratory 1980) implied that decomposition may be rapid when organically rich material is deposited. Graf et al. (1983) also found no time lag in the response of benthic metabolic activity to sedimentation of the spring bloom in Kiel Bight with complete consumption in 4 to $5 \mathrm{wk}$.

If unoxidized products are buried, then organic carbon utilization can be calculated indirectly assuming a steady-state over the year as the difference between sedimentation and burial rates (Suess 1980). Deposition of particulate organic carbon and nitrogen at $22 \mathrm{~m}$ between May and October (184 d) (1978) was $28.8 \mathrm{~g} \mathrm{C}$ and $4.5 \mathrm{~g} \mathrm{~N} \mathrm{~m}^{-2}$. If rates measured during the unstratified period are extrapolated to the remainder of the year, recognizing that this would not necessarily 
reflect sedimentation during the winter bloom mentioned above, conservative estimates of annual sedi-

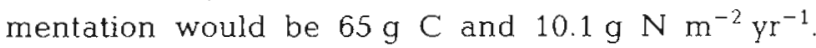
Subtraction of estimated annual burial rates $(3 \mathrm{~g} \mathrm{C}$ and $0.4 \mathrm{~g} \mathrm{~N}$ ) yields $62 \mathrm{~g} \mathrm{C}$ and $9.7 \mathrm{~g} \mathrm{~N} \mathrm{~m}^{-2} \mathrm{yr}^{-1}$ for benthic utilization and mineralization. These rates, averaged over the year, are slightly lower than measurements of total carbon released by benthic respiration and inorganic nitrogenous nutrient flux (Fig. 2 \& 3). However, total inorganic nitrogen release was underestimated because $\mathrm{N}_{2}$ loss was not measured. If sedimentation rates measured at $32 \mathrm{~m}$ are considered, calculated rates of deposition (-burial) $\left(223 \mathrm{~g} \mathrm{C}\right.$ and $43.7 \mathrm{~g} \mathrm{~N} \mathrm{~m}^{-2}$ $\mathrm{yr}^{-1}$ ) exceed benthic fluxes by 3 to 4 times. However, sedimentation rates are overestimated because of resuspension at this depth.

The turnover rates of organic carbon and nitrogen in sediments can be calculated as the ratio of metabolic losses to standing stock if a steady state exists between organic matter accumulated and that added over time. It is assumed that a steady state occurs over an annual period and that most $(>90 \%)$ of the organic matter added during $1 \mathrm{yr}$ is mineralized. This occurred in St. Georges Bay since burial rates were small relative to metabolic losses. Assuming the specific gravity of sediment to be $2.6 \mathrm{~g} \mathrm{~cm}^{-3}$ and a water content of $70 \%$ (porosity of 0.70 ), average organic carbon and nitrogen content as percent dry weight over the upper $10 \mathrm{~cm}$ layer $(\% \mathrm{C}=0.97 \pm 0.44 \%, \mathrm{~N}=0.12 \pm 0.08 \%$; Fig. 4) yields a steady state concentration of $300 \pm$ $136 \mathrm{~g} \mathrm{C} \mathrm{m}^{-2}$ and $40 \pm 20 \mathrm{~g} \mathrm{~N} \mathrm{~m}^{-2}$. Daily rates of benthic carbon and nitrogenous nutrient release during stratified and unstratified periods extrapolated over the year ( $85.3 \mathrm{~g} \mathrm{C} \mathrm{m}^{-2} \mathrm{yr}^{-1}$ and $3.7 \mathrm{~g} \mathrm{~N} \mathrm{~m}^{-2} \mathrm{yr}^{-1}$ ) yield annual turnover rates of 0.2 to $0.5 \mathrm{yr}^{-1}$ for carbon and 0.06 to $0.2 \mathrm{yr}^{-1}$ for nitrogen. If rates of benthic flux calculated above as the difference between sedimentation at $22 \mathrm{~m}$ and burial rates are used in the comparison, annual organic carbon and nitrogen tumover rates are 0.14 to 0.38 and 0.16 to 0.50 , respectively. The latter values would include nitrogen lost through denitrification from sediments as $\mathrm{N}_{2}$.

Calculations of turnover times for sediment organic matter depend on the assumed depth over which material is exchanged. Calculated values (0.2 to 1.0$)$, for carbon, are similar to observations in other coastal marine sediments when exchanges are considered to occur to depths greater than the upper few centimeters (Jorgensen 1977. Hargrave \& Phillips 1981). The welloxidized surface sediment and stratigraphy disturbed by bioturbation to $10 \mathrm{~cm}$ (Schafer \& Mudie 1980) in St. Georges Bay indicate that mixing of sediment and pore water exchange could occur to this depth. Variability in estimates of nitrogen turnover reflect the underestimate in benthic nitrogen flux when only nitrogenous nutrients, and not total inorganic nitrogen including $\mathrm{N}_{2}$, are measured.

The long turnover time ( 3 to $10 \mathrm{yr}$ ) for organic carbon and nitrogen in sediments contrasts the rapid turnover of suspended particulate matter in St. Georges Bay. Suspended concentrations above $15 \mathrm{~m}(0.7$ to $4.6 \mathrm{~g} \mathrm{C}$ $\mathrm{m}^{-2}$ and 0.1 to $0.5 \mathrm{~g} \mathrm{~N} \mathrm{~m}^{-2}$ ) observed between June and October (Marine Ecology Laboratory 1980) and calculated values of pelagic respiration and mineralization derived from Fig. 2 \& 3 for the same depth interval and expressed on an annual basis (27 to $53 \mathrm{~g} \mathrm{C}$ $\mathrm{m}^{-2} \mathrm{yr}^{-1}, 5$ to $9 \mathrm{~g} \mathrm{~N} \mathrm{~m}^{-2} \mathrm{yr}^{-1}$ ) yield tumover times of 6 to $76 \mathrm{yr}^{-1}$ for organic carbon and 10 to $90 \mathrm{yr}^{-1}$ for nitrogen. The range of values ( 4 to $61 \mathrm{~d}$ ) is similar to that calculated for suspended particles in the upper ocean (1.2 to 24 d) (Eppley et al. 1983).

\section{Comparisons of pelagic and benthic secondary production and food web transfer efficiencies}

Production by pelagic and benthic organisms has been calculated by previous workers either by direct measurement or by applying $\mathrm{P}: \mathrm{B}$ ratios to biomass measurements as in the present study (Table 3 ). Results were tabulated on a daily basis for comparison with data from St. Georges Bay since in many cases annual production was not determined but calculated from seasonal measurements. The estimates are useful for comparing the relative magnitude of organic matter transfer calculated in different studies.

Estimates of production by benthic macrofauna and demersal fish in St. Georges Bay are characteristic of moderately productive coastal and continental shelf waters. In some cases similarities in estimates of production result from applying equivalent annual turnover ratios to similar values of biomass. For example, macrobenthos in Long Island Sound and St. Georges Bay have a similar standing crop (approximately $10 \mathrm{~g}$ $\mathrm{C} \mathrm{m}^{-2}$ ) and similar annual turnover ratios (2.4 derived from calculated production rates by Sanders [1956] and 2 assumed in the present study). Low estimates of demersal fish production in Long Island Sound and on the Bering Sea Shelf and for macrobenthos and demersal fish on shelves in the Gulf of Mexico contrast values in other studies. Low rates of primary production could account for the differences but high rates of phytoplankton production in Long Island Sound and the Bering Sea might have been expected to result in higher levels of secondary production. Variations may also reflect the inclusion of different ages of fish in population estimates. For example, only juvenile demersal fish were included in the estimate of production in Long Island Sound.

Richards \& Riley (1967) discussed the magnitude of 
Table 3. Comparison of annual or seasonal estimates of phytoplankton (with macrophytes where measured), macrozooplankton, macrobenthos and demersal fish production $\left(\mathrm{mg} \mathrm{C} \mathrm{m}^{-2} \mathrm{~d}^{-1}\right)$ from various marine locations ranked by increasing depth. - No data. Ranges derived from seasonal or geographic differences within a study

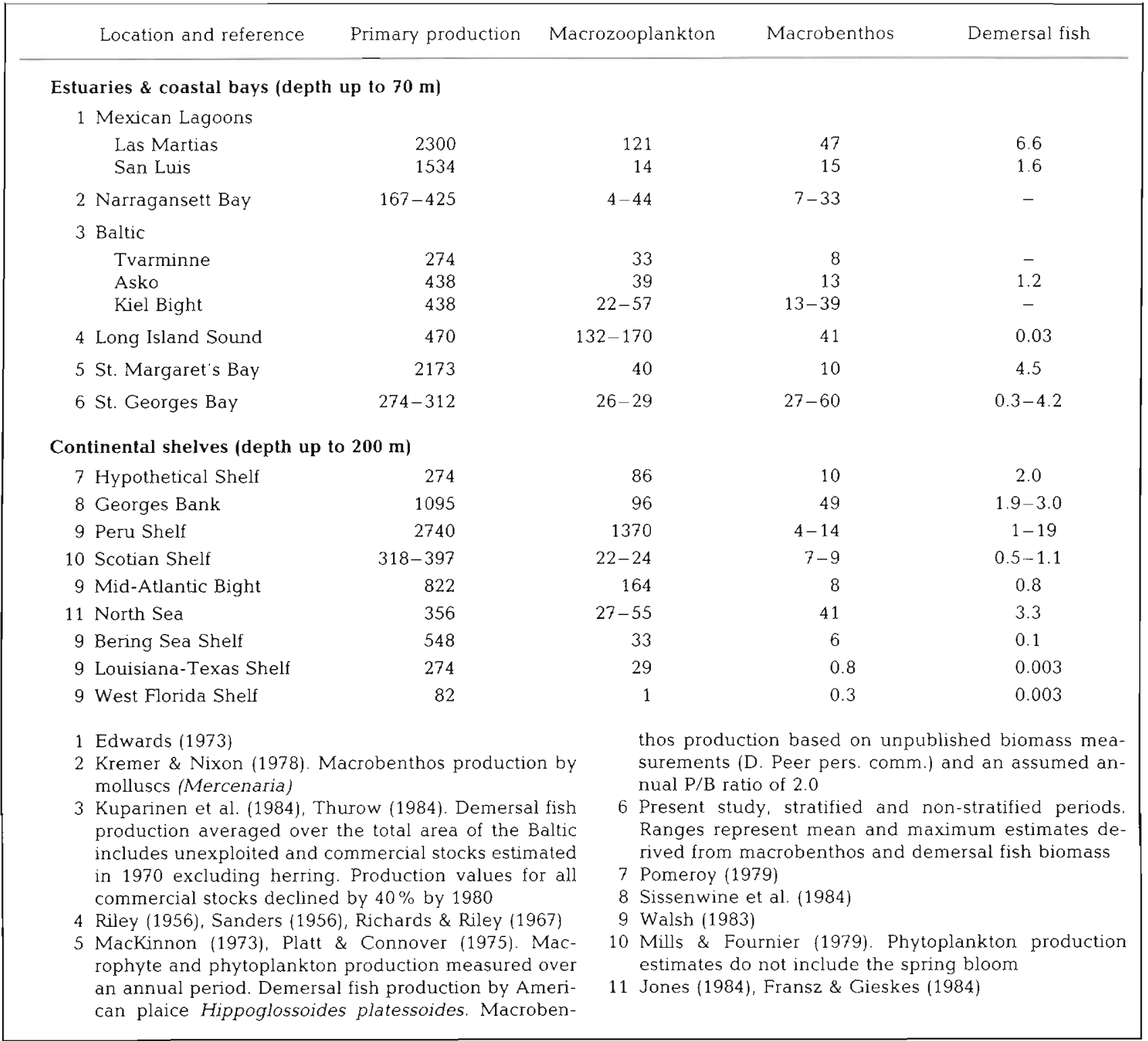

production by epibenthic predators (echinoderms, crustaceans) in Long Island Sound. Although competition with demersal fish for the same food source was not thought to occur, organic matter entering the benthos was not in a form useable by bottom feeding fish. Mills (1975) also discussed the competition and structural differences which might occur between benthic communities dominated by infauna in depositional sediments and epifauna on hard substrates. Food availability to demersal fish may be lower when infauna dominate the benthic biomass. This would not seem to be the situation in St. Georges Bay where maximum demersal fish production based on an upper biomass estimate is high and similar to values in nondepositional shelf environments such as Georges Bank and the Scotian Shelf.

Calculated macrobenthos production in St. Georges Bay amounts to from 20 to $45 \%$ of average particulate organic carbon sedimentation for stratified and unstratified periods at $22 \mathrm{~m}$ (Fig. 2). The range of values is similar to high transfer efficiencies required in earlier studies to balance energy flow between pelagic and benthic populations (Mills \& Fournier 1979, Pomeroy 1979, Walsh 1983, Jones 1984). Also, production values may be overestimated by use of a $\mathrm{P}: \mathrm{B}$ ratio of 2. Even though some species consume other fish as 
well as benthic macrofauna, if demersal fish are considered to feed only on macrobenthos their production is equivalent to $\approx 1$ to $7 \%$ of macrobenthos production. The comparison shows a high efficiency between predator and prey links in the benthos as was also inferred for the pelagic food web in the Bay.

Mann (1975) pointed out that morphometric and hydrographic features affect the type and amount of primary production which occur in coastal waters and also control exchange with offshore waters. Low macrobenthos production in St. Margaret's Bay where primary production is high (Table 3), for example, could reflect flushing and exchange with offshore waters that occur frequently and remove products of phytoplankton and macrophyte production. Macrobenthos production in continental shelf environments such as the Bering Sea, off the coast of Nova Scotia and the mid-Atlantic Bight is a small proportion $(<2 \%)$ of estimated phytoplankton production (Table 3$)$. These are areas where advection probably exports a significant proportion of organic matter offshore into deeper water before consumption has occurred either in the water column or by the benthos (Walsh 1983). Advective loss to offshore areas through water transport or high sedimentation rates could also explain the high variability in rates of macrozooplankton production (1 to $20 \%$ of primary production) in different studies. In contrast, a large proportion of particulate matter produced in many estuarine and coastal areas less subject to advective transport, such as St. Georges Bay, remain to be consumed for production of macrobenthos and demersal fish. High levels of macrobenthos production, equivalent to 10 to $20 \%$ of primary production, indicates a high efficiency which may be realized in the food web when the morphology and hydrographic features of an area result in the retention of products of primary production.

Acknowledgements. We gratefully acknowledge the assistance of Nick Prouse who measured phytoplankton production and helped with studies of particulate matter sedimentation, and of Don Peer who collected, identified and enumerated benthic macrofauna

\section{LITERATURE CITED}

Andrews, D. (1980). The prediction and measurement of dissolved silicate flux across marine sediments. Ph.D. dissertation, Dalhousie University

Banse, K., Mosher, S. (1980). Adult body mass and annual production/biomass relationships of field populations. Ecol. Monogr. 50: 355-379

Boynton, W R., Kemp., W M. (1985). Nutrient regeneration and oxygen consumption by sediments along an estuarine salinity gradient. Mar Ecol. Prog. Ser. 23: 45-55

Dale, T. (1978). Total, chemical and biological oxygen consumption of the sediments in Lindasspollene, Western Norway. Mar. Biol. 49: 333-341
Davies, J. M. (1975). Energy flow through the benthos in a Scottish sea loch. Mar Biol. 31: 353-362

Edwards, R. R. C. (1973). Production ecology of two Caribbean marine ecosystems. I. Physical environment and fauna. II. Metabolism and energy flow. Estuar. coastal mar. Sci. 1: 303-333

Eppley, R. W., Peterson, B. J. (1979). Particulate organic matter flux and planktonic new production in the deep ocean. Nature, Lond. 282: 677-680

Eppley, R. W., Renger, E., Betzer, P. R. (1983). The residence time of particulate organic carbon in the surface layer of the ocean. Deep Sea Res. 311-323

Es, F. B. van (1982). Community metabolism of untertidal flats in the Ems-Dollard Estuary. Mar. Biol. 66: 95-108

Fisher, T R., Carlson, P. R., Barber, R. T (1982). Sediment nutrient regeneration in three North Carolina estuaries. Estuar. coast. Shelf Sci. 14: 101-116

Flint, R. W., Kamykowski, D. (1984). Benthic nutrient regeneration in south Texas coastal waters. Estuar. coast. Shelf Sci. 18: 218-225

Fransz, H. G., Gieskes, W. W. C. (1984). The unbalance of phytoplankton and copepods in the North Sea. Rapp. P.-v. Réun. Cons. int. Explor. Mer 183: 218-225

Garside, C., Malone, T. C. (1978). Monthly oxygen and carbon budgets of the New York Bight Apex. Estuar. coastal mar. Sci. 6: 93-104

Graf, G., Schulz, R., Peinert, R., Meyer-Reil, L.-A. (1983). Benthic response to sedimentation events during autumn to spring at a shallow-water station in the Western Kiel Bight. Mar. Biol. 77: 235-246

Graf, G., Bengtsson, W., Faubel, A., Meyer-Reil, L.-A., Schulz, R., Theede, H. (1984). The importance of the spring bloom for the benthic system Kiel Bight. Rapp. P.-v. Réun. Cons. int. Explor Mer 183: 136-143

Hargrave, B. T (1969). Similarity of oxygen uptake by benthic communities. Limnol. Oceanogr. 14: 801-805

Hargrave, B. T (1973). Coupling carbon flow through some pelagic and benthic communities. J. Fish. Res. Bd Can. 30: $1317-1326$

Hargrave, B. T (1978). Geochemical and biological observations in intertidal sediments from Cobequid Bay, Bay of Fundy, Nova Scotia. Fish. Mar. Serv. Res. Dev. Tech. Rep. No. 782: 1-43

Hargrave, B. T. (1980). Factors affecting the flux of organic matter to sediments in a marine bay. In: Tenore, $K$. R., Coull, B. C. (ed.) Marine benthic dynamics. Univ. of South Carolina, Columbia, p. 243-263

Hargrave, B. T. (1984). Sinking of particulate matter from the surface water of the ocean. In: Hobbie, J. E, Williams, P. J. LeB. (ed.) Heterotrophic activity in the sea. Plenum Publ., New York, p. 155-178

Hargrave, B. T., Connolly, G. F. (1978). A device to collect supernatant water for measurements of the flux of dissolved compounds across sediment surfaces. Limnol. Oceanogr 23: 1005-1010

Hargrave, B. T., Harding, G. C., Drinkwater, K. F., Lambert, T. C., Harrison, W. G. (1985). Dynamics of the pelagic food web in St. Georges Bay, southern Gulf of St. Lawrence. Mar. Ecol. Prog. Ser 20: 221-240

Hargrave, B. T., Phillips, G. A. (1981). Annual in situ carbon dioxide and oxygen flux across a subtidal marine sediment. Estuar coast. Shelf Sci. 12: 725-737

Hargrave, B. T., Prouse, N. J. (1981). Observations of dissolved nutrients, phytoplankton biomass, sedimentation and sediment organic matter in St. Georges Bay, 1978. Can. Tech. Rept. Fish. Aquat. Sci. 1001: 1-91

Harrison, W G. (1978). Experimental measurements of nitro- 
gen remineralization in coastal waters. Limnol. Oceanogr 23: $684-694$

Harrison, W. G. (1980). Nutrient regeneration and primary production in the sea. In: Falkowski, P. G. (ed.) Primary productivity in the sea. Plenum Publ., New York. p. $433-460$

Harrison, W. G., Douglas, D., Falkowsk,, P., Rowe, G., Vidal, J. (1983). Summer nutrient dynamics of the Middle Atlantic Bight: nitrogen uptake and regeneration. J. Plankton Res. 5: 539-556

Hartwig, E. O. (1976). Nutrient cycling between the water column and a marine sediment. 1. Organic carbon. Mar. Biol. 34: 285-295

Helder, W., de Vries, R. T. P., Rutgers van der Loeff, M. M. (1983). Behavior of nitrogen nutrients and silica in the Ems-Dollard Estuary. Can. J. Fish. Aquat. Sci. 40 (Suppl. 1): $188-200$

Hopkinson, C. S., Wetzel, R. L. (1982). In situ measurements of nutrient and oxygen fluxes in a coastal marine benthic community. Mar. Ecol. Prog. Ser. 10: 29-35

Howes, B. L., Dacey, J. W. H., King, G. M. (1984). Carbon flow through oxygen and sulfate reduction pathways in salt marsh sediments. Limnol. Oceanogr. 29: 1037-1051

Jamart, B. M., Winter, D. F., Banse, K. (1979). Sensitivity analysis of a mathematical model of phytoplankton growth and nutrient distribution in the Pacific Ocean off the Northwestern U.S. coast. J. Plankton Res. 1: 267-290

Jones, R. (1984). Some observations on energy transfer through the North Sea and Georges Bank food webs. Rapp. P.-v. Réun. Cons. int. Explor Mer 183: 204-217

Jergensen, B. B. (1977). The sulfur cycle of a coastal marine sediment (Limfjorden, Denmark). Limnol. Oceanogr 22: 814-832

Jørgensen, B. B. (1982). Mineralization of organic matter in the seabed - the role of sulphate reduction. Nature, Lond. 296: $643-645$

Kenchington, T. J. (1980). The fishes of St. Georges Bay, Nova Scotia. Can. Tech. Rept. Fish. Aquat. Sci. 955: 1-154

Komar, P. D., Morse, A. P., Small, L. F., Fowler, S. W. (1981). An analysis of sinking rates of natural copepod and euphausiid fecal pellets. Limnol. Oceanogr 26: 172-180

Kremer, J. N., Nixon, S. W. (1978). A coastal marine ecosystem simulation and analysis. Springer Verlag, New York

Kuparinen, J., Leppanen, J.-M., Sarvala, J., Sundberg, A., Virtanen, A. (1984). Production and utilization of organic matter in a Baltic ecosystem off Tvarminne, southwest coast of Finland. Rapp. P.-v. Réun. Cons. int. Explor. Mer 183: $180-192$

Lewis, A. G., Syvitski, J. P. M. (1983). The interaction of plankton and suspended sediment in fjords. Sediment. Geol. 36: 81-92

Lyons, W. B., Loder, T., Murray, S. M. (1982). Nutrient pore water chemistry, Great Bay, New Hampshire: benthic fluxes. Estuaries 5: 230-233

Mackinnon, J. C. (1973). Analysis of energy flow and production in an unexploited marine flatfish population. J. Fish. Res. Bd Can. 30: 1717-1728

Mann, K. H. (1975). Relationship between morphometry and biological functioning in three coastal inlets of Nova Scotia. In: Cronin, L. E. (ed.) Estuarine research, Vol. 1 Academic Press, New York, p. 634-644

Mann, K. H. (1982). Ecology of coastal waters. Blackwell, Oxford

Marine Ecology Laboratory (1980). Physical oceanography, dissolved nutrients, phytoplankton production, plankton biomass and sedimentations in St. Georges Bay, N.S., 1977. Can. Tech. Rept. Fish. Aquat. Sci. 934: 1-162
Mills, E. L. (1975). Benthic organisms and the structure of marine ecosystems. J. Fish. Res. Bd Can. 32: 1657-1663

Mills, E. L., Fournier, R. O. (1979). Fish production and the marine ecosystems of the Scotian Shelf, Eastern Canada. Mar Biol. 54: 101-108

Nixon, S. W., Oviatt, C. A., Hale, S. S. (1976). Nitrogen regeneration and the metabolism of coastal marine bottom communities. In: Anderson, J. M., Macfadyen, A. (ed.) The role of terrestrial and aquatic organisms in decomposition processes. Blackwell, Oxford, p. 269-283

Nixon, S. W., Kelly, J. R., Furnas, B. N., Oviatt, C. A., Hale, S. S. (1980). Phosphorus regeneration and the metabolism of coastal marine bottom communities. In: Tenore, K. R., Coull, B. C. (ed.) Marine benthic dynamics. Univ. of South Carolina, Columbia, p. 219-242

Pamatmat, M. M. (1971). Oxygen consumption by the seabed IV Shipboard and laboratory experiments. Limnol. Oceanogr. 16: 536-550

Parsons, T R., Takahashi, M., Hargrave, B. (1984). Biological oceanographic processes. 3rd edn. Pergamon Press, Toronto

Petrie, B., Drinkwater, K. (1978). Circulation in an open bay. J. Fish. Res. Bd Can. 35: 1116-1123

Platt, T., Conover, R. J. (1975). The ecology of St. Margaret's Bay and other inlets on the Atlantic coast of Nova Scotia. In: Cameron, T. W., Billingsley, L. W. (ed.) Energy flow its biological dimensions. Roy. Soc. Canada, Ottawa, p. $249-259$

Pomeroy, L. R. (1974). The ocean's food web, a changing paradigm. Bioscience 24: 499-504

Pomeroy, L. R. (1979). Secondary production mechanisms of continental shelf communities. In: Livingston, R. J. (ed.) Ecological processes in coastal and marine systems. Plenum Publ., New York, p. 163-186

Propp, M. V., Tarasoff, V G., Cherbadgi, I. I., Lootzik, N. V. (1980). Benthic-pelagic oxygen and nutrient exchange in a coastal region of the Sea of Japan. In: Tenore, K. R., Coull, B. C. (ed.) Marine benthic dynamics. Univ. of South Carolina, Columbia, p. 265-284

Prouse, N. J., Hargrave, B. T (1977). Chlorophyll, carbon and nitrogen in suspended and sedimented particulate matter in St. Georges Bay, Nova Scotia. Fish. Mar. Serv. Tech. Rept. 721: 1-69

Raine, R. C. T., Patching, J. W. (1980). Aspects of carbon and nitrogen cycling in a shallow marine environment. $J$. exp. mar. Biol. Ecol. 47: 127-139

Reimers, C. E., Suess, E. (1983). The partitioning of organic carbon fluxes and sedimentary organic matter decomposition rates in the ocean. Mar. Chem. 13: 141-168

Richards, S. W., Riley, G. A. (1967). The benthic epifauna of Long Island Sound. Bull. Bingham oceanogr. Coll. 19: 89-135

Riley, G. A. (1956). Oceanography of Long Island Sound, 1952-1954. IX. Production and utilization of organic matter. Bull. Bingham oceanogr. Coll. 15: 324-344

Rosenfeld, J. K. (1979). Ammonium adsorption in nearshore anoxic sediments. Limnol. Oceanogr. 24: 356-364

Rutgers van der Loeff, M. M., Es, F. B. van, Helder, W., de Vries, R. T. P. (1981). Sediment water exchanges of nutrients and oxygen on tidal flats in the Ems-Dollard estuary. Neth. J. Sea Res. 15: 113-129

Sanders, H. L. (1956). Oceanography of Long Island Sound, 1952-1954. X. The biology of marine bottom communities. Bull. Bingham oceanogr. Coll. 15: 345-414

Schafer, C. T., Mudie, P. J. (1980). Spatial variability of foraminifera and pollen in two nearshore sediment sites, St. Georges Bay, Nova Scotia. Can. J. Earth Sci. 17: 313-324 
Seitzinger, S. P., Nixon, S. W., Pilson, M. E. Q. (1984). Denitrification and nitrous oxide production in a coastal marine ecosystem. Limnol. Oceanogr 29: 73-83

Sharp, J. H. (1973). Size classes of organic carbon in seawater Limnol. Oceanogr 18: 441-447

Sissenwine, M. P., Cohen, E. B., Grosslein, M. D. (1984) Structure of the Georges Bank ecosystem. Rapp. P.-v. Réun. Cons. int. Explor. Mer 183: 243-254

Smetacek, V. (1980). Annual cycles of sedimentation in relation to plankton ecology in western Kiel Bight. Ophelia 1 (Suppl.): $65-76$

Smetacek, V., von Bodungen, B., Knoppers, B., Peinert, R., Pollehne, F., Stegamann, P., Zeitzschel, B. (1984). Seasonal stages characterizing the annual cycle of an inshore pelagic system. Rapp. P.-v. Réun. Cons. int. Explor. Mer 183: $126-135$

Smith, K. L., Jr., Laver, M. B., Brown, N. O. (1983). Sediment community oxygen consumption and nutrient exchange in the central and eastern North Pacific. Limnol. Oceanogr. 28: $882-898$

Steele, J. H. (1974). The structure of marine ecosystems Harvard Univ. Press, Cambridge, Massachusetts

Strickland, J. D. H., Parsons, T. R. (1972). A practical handbook of seawater analysis. Bull. Fish. Res. Bd Can. 167: $1-311$

Suess, E. (1980). Particulate organic carbon flux in the oceans - surface productivity and oxygen utilization. Nature, Lond. 288: 260-263
Taft, J. L., Taylor, W. R., Hartwig, E. O., Loftus, R. (1980). Seasonal oxygen depletion in Chesapeake Bay. Estuaries 3: $242-247$

Thurow, F. (1984). Growth production of the Baltic fish community. Rapp. P.-v. Réun. Cons. int. Explor Mer 183: $170-179$

Walsh, J. J. (1983). Death in the sea: enigmatic phytoplankton losses. Prog. Oceanogr. 12: 1-86

Webster, I J. M., Paranjape, M. A., Mann, K. H. (1975) Sedimentation of organic matter in St. Margaret's Bay Nova Scotia. J. Fish. Res. Bd Can. 32: 1399-1407

Williams, P. J. LeB. (1984). A review of measurements of respiration rates of marine plankton populations. In: Hobbie, J. E., Williams, P. J. LeB. (ed.) Heterotrophic activity in the sea. Plenum Publ., New York, p. 357-389

Woodwell, G. M., Houghton, R. A., Hall, C. A. S., Whitney, D. E., Moll, R. A., Juers, D. W. (1979). The Flax Pond ecosystem study: the annual metabolism and nutrient budgets of a salt marsh. In: Jeffries, R. L., Davy, A. J. (ed.) Ecological processes in coastal environments. Blackwell, Oxford, p. 491-511

Zeitzschel, B. (1980). Sediment-water interactions in nutrient dynamics. In: Tenore, K. R., Coull, B. C. (ed.) Marine benthic dynamics. Univ. of South Carolina, Columbia, p. 195-218

This article was presented by Dr. G. Harding; it was accepted for printing on April 10, 1986 